\title{
Intrinsic and Extrinsic Factors Governing the Transcriptional Regulation of ESR1
}

\author{
David K. Lung ${ }^{1}$ (D) - Rebecca M. Reese ${ }^{1}$ (D) - Elaine T. Alarid ${ }^{1,2}$ (D) \\ Received: 18 April 2020 / Accepted: 2 June 2020 / Published online: 26 June 2020 \\ (C) Springer Science+Business Media, LLC, part of Springer Nature 2020
}

\begin{abstract}
Transcriptional regulation of ESR1, the gene that encodes for estrogen receptor $\alpha(E R)$, is critical for regulating the downstream effects of the estrogen signaling pathway in breast cancer such as cell growth. ESRI is a large and complex gene that is regulated by multiple regulatory elements, which has complicated our understanding of how ESR 1 expression is controlled in the context of breast cancer. Early studies characterized the genomic structure of ESR1 with subsequent studies focused on identifying intrinsic (chromatin environment, transcription factors, signaling pathways) and extrinsic (tumor microenvironment, secreted factors) mechanisms that impact ESR1 gene expression. Currently, the introduction of genomic sequencing platforms and additional genome-wide technologies has provided additional insight on how chromatin structures may coordinate with these intrinsic and extrinsic mechanisms to regulate ESR 1 expression. Understanding these interactions will allow us to have a clearer understanding of how ESR1 expression is regulated and eventually provide clues on how to influence its regulation with potential treatments. In this review, we highlight key studies concerning the genomic structure of ESR1, mechanisms that affect the dynamics of ESR 1 expression, and considerations towards affecting ESR1 expression and hormone responsiveness in breast cancer.
\end{abstract}

Keywords Steroid receptor · Gene expression · Transcription · Chromatin

\section{Introduction}

An important predictive and prognostic biomarker found in the majority of breast cancers is estrogen receptor $\alpha$ (ER) [1-3]. ER is a transcription factor of the nuclear receptor superfamily that mediates the effects of estrogen ligands and promotes growth and cell survival [4]. Approximately 60$70 \%$ of breast cancers are classified as ER-positive, and the proportion of ER-positive cases is forecasted to increase significantly within the next 20 years, while the number of ERnegative cases is expected to decline for unclear reasons [5]. This forecast highlights the need to understand what controls ER status during disease progression. ER-positive breast cancers are defined histologically as $1 \%$ of tumor nuclei with

Elaine T. Alarid

alarid@oncology.wisc.edu

1 McArdle Laboratory for Cancer Research, Department of Oncology and Carbone Comprehensive Cancer Center, University of Wisconsin-Madison, Madison, WI, USA

26151 Wisconsin Institutes for Medical Research, Madison, WI 53705, USA detectable ER protein [6]. Examination of ER expression through mammary tumor development indicate that ER heterogeneity varies throughout cancer progression [7]. However, despite observing a small subpopulation of cells expressing ER, the frequency of ESR1 mRNA detection in recent single-cell sequencing studies on normal mammary gland and breast cancer cells suggest that ESR1 expression is biologically important in both normal mammary gland tissues and breast cancer [6, 8-16].

ER is the primary target of endocrine therapies due to its significant role in ER-positive breast cancer proliferation and survival, but the development of resistance to these therapies inevitably occurs despite their initial effectiveness $[17,18]$. A higher level of ESR1 expression in ER-positive breast cancer patients correlates with a significantly longer relapse-free survival time (Fig. 1) [19]. However, clinical studies have shown that metastatic tumors, the major cause of breast cancer patient mortality, generally contain relatively lower levels of ER compared to that of the primary tumor [20]. Furthermore, Dieci et al. compared survival rates between breast cancer patients with tumors that maintained high ER expression or transitioned to low ER expression and observed decreased overall survival rates in the latter group [21]. Because there 
ESR1 (205225_at)

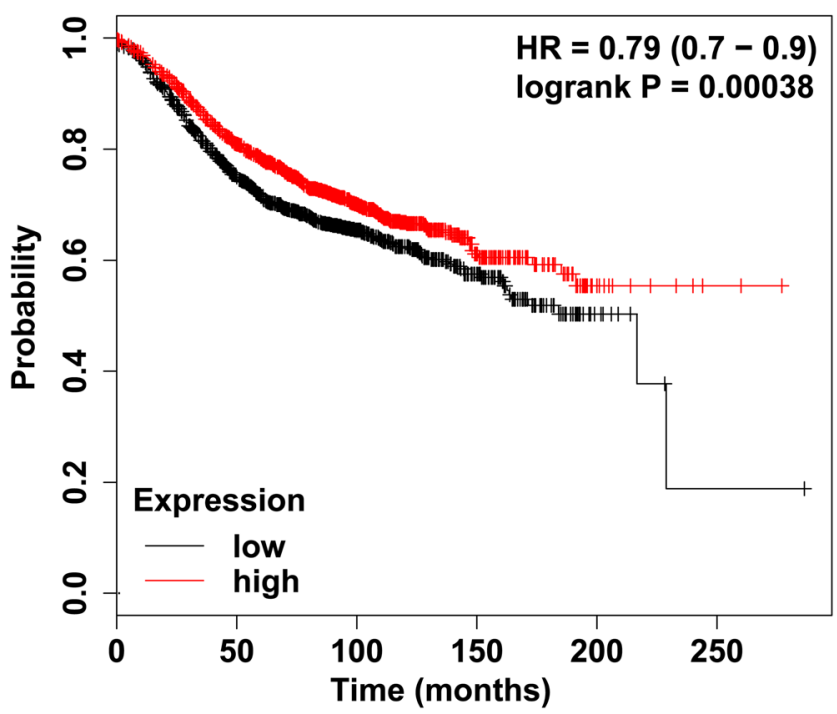

Fig. 1 Kaplan-Meier plot showing the probability of relapse-free survival over time based on ESR1 expression levels (Affymetrix gene ID ESR1 205225 at). This plot was generated using the KM Plotter tool [9]. The patient cohort was restricted to ER+ breast cancer samples where ER status was derived from gene expression data $(n=3082)$. Samples were split into high and low expression groups relative to the median expression of ESRI in the patient cohort [19]

is a direct correlation between cellular levels of ER and ER transcriptional activity/hormone sensitivity and poorer prognosis in ER-negative breast tumors, decreases in ER expression may be a major mechanism that reduces hormonedependent control in breast cancers [22-25].

Transcriptional regulation of ESR1, the gene that encodes for ER, is an essential component of maintaining hormone sensitivity in breast cancer cells. While other levels of regulation are known to regulate ER expression (posttranscriptional and posttranslational mechanisms), in vitro and clinical studies involving ER-negative cell lines and patient data, respectively, suggest transcriptional control of ESR1 is the main driver in the dysregulation of ER expression [26-35]. This finding is supported by a modeling study of estrogen regulation of ER expression, which indicates that ESR1 is the primary controller of cellular ER levels and this control of the ESRl gene is facilitated by the interaction between the phosphorylated ER (a transcriptionally active form of ER) and the ESR1 promoter. [36]. It should be noted that approximately 20-25\% of ER-negative tumors still express detectable levels of ESR1 mRNA, which shows that, in this subset of tumors, ER may be regulated by posttranscriptional and/or posttranslational mechanisms [37-39]. To study transcriptional regulation, multiple assays have been employed to assess the activity of regulatory elements associated with a gene, the occupancy of essential transcription initiators such as transcription factors, RNA polymerase II (Pol II) and Mediator, and levels of nascent or immature mRNA. In addition to these intrinsic mechanisms, extrinsic factors are also known to regulate ESR1 expression. Therefore, this review will provide an overview of the ESRI gene and focus on intrinsic and extrinsic transcriptional mechanisms regulating the ESRI gene.

\section{Characterization of the ESR1 Gene}

The ESR 1 gene has been characterized and studied extensively over the past three decades; however, questions remain on how the ESR 1 gene is regulated due to its inherent complexity. The human ESR1 gene was first cloned from the ER-positive MCF-7 breast cancer cell line by Walter et al., and their findings were further expanded to cover the entire ESR1 mRNA by Green et al. [40, 41]. Subsequent studies on the cloned ESR1 gene focused on identifying regulatory elements associated with ESR1 [42-48]. Kos et al. provides an overview of these studies and a nomenclature for the ESR1 gene that consolidated the reported regulatory regions (Fig. 2a, b) [49]. It should be noted that some of these regulatory regions are expressed in a tissue-specific context, specifically the $\mathrm{T} 1$ and T2 promoters in human epididymis and testes [50]. The ESRI gene spans approximately 300 kilobases $(\mathrm{kb})$ on chromosome 6 (chr6) and consists of eight regulatory elements. Based on the genomic coordinates described by Kos et al., the transcription start site (TSS) of ESR1 begins on chr6:152128814 152129050 in the hg19 assembly published in the UCSC Genome Browser [51]. This region also contains the common acceptor splice site for all ESRI mRNA variants $(+164)$ to form a single $E S R 1$ mRNA transcript. The coordinates of the TSS and regulatory elements of ESRI are shown in Fig. 2c.

Given that there are multiple regulatory elements of ESR1, it is important to determine how each element is utilized. Using reporter gene assays and quantifying ESR1 mRNA expressed from seven promoter regions, MCF-7, T47D, and ZR-75-1 cells, which are major models of ER-positive breast cancers, primarily utilize the A promoter (also known as the proximal promoter) with less activity detected in the B and C promoters [45, 52-54]. Similarly, in ER-positive primary patient samples, ESR1 transcripts overlapping the A promoter were detected most frequently followed by those overlapping the $\mathrm{C}$ promoter [54]. In addition to these promoters, a distal enhancer site (ENH1) is approximately $150 \mathrm{~kb}$ from the TSS and has also been reported to regulate ESR1. Given the significance of ER to mammary gland development, Eeckhoute et al. investigated the relationship between ER and GATA3, a transcription factor that is an essential regulator of mammary gland differentiation and morphogenesis in mice [55-57]. They used T47D cells and determined that GATA3 was recruited to ENH1 along with Pol II in order to regulate ESRI expression. A study from our group also showed that the proteasome inhibitor bortezomib represses ESR1 expression via induction of a repressive chromatin environment on ENH1 in 
(a) ESR1
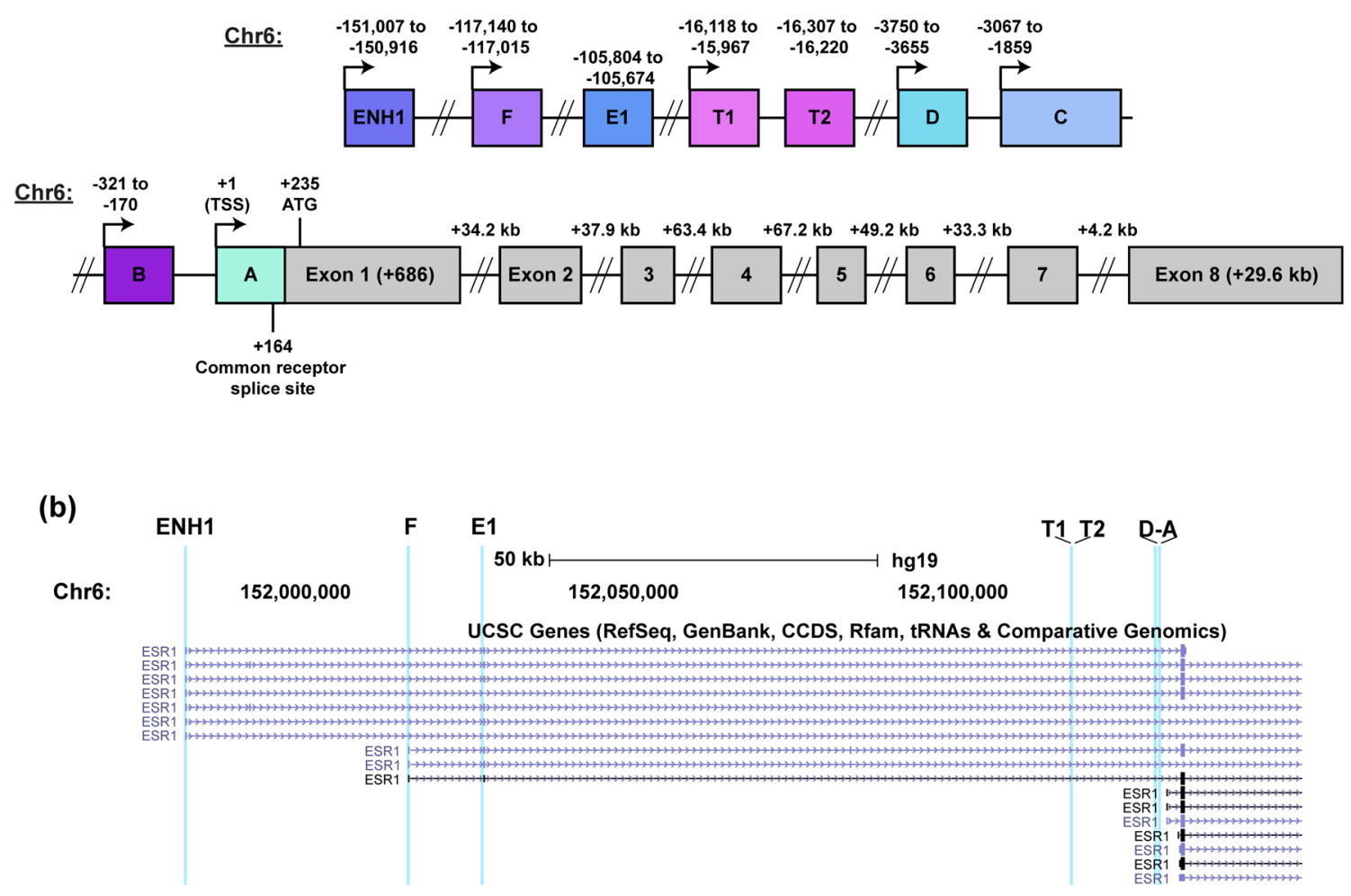

(c)

\begin{tabular}{lc}
\hline Key Sites/Regulatory Element & \multicolumn{1}{c}{ Genomic Location } \\
\hline TSS (+1) to ATG (+235) & chr6:152,128,814-152,129,050 \\
A promoter (proximal promoter) & chr6:152,128,814-152,128,977 \\
B promoter & chr6:152,128,492-152,128,643 \\
C promoter & chr6:152,125,746-152,126,954 \\
D promoter & chr6:152,125,063-152,125,158 \\
T2 promoter & chr6:152,112,695-152,112,846 \\
T1 promoter & chr6:152,112,506-152,112,593 \\
E1 & chr6:152,023,009-152,023,139 \\
F promoter & chr6:152,011,673-152,011,798 \\
ENH1 (distal enhancer) & chr6:151,977,806-151,977,897
\end{tabular}

Fig. 2 Diagram of the ESRI gene (chromosome 6). a ESRI is approximately 300 kilobases and consists of several reported regulatory elements with some promoters utilized in a tissue-specific manner and eight exons. The nomenclature and numbering used in this diagram are based on NM_000125 and described by Kos et al. [49]. Diagram is not drawn to scale. b ESR1 transcript variants differ by their 5' UTR but are spliced to the same acceptor splice site shown in a. Shown is a screenshot of ESR1 variants on the UCSC Genome Browser (human assembly hg19) with ESR 1 regulatory regions highlighted in light blue (chr6:151,968,286-152,147,486). c Genomic coordinates listed of key sites and regulatory elements of ESR1. Genomic coordinates start from the transcription start site $(+1)$ and are based on the ESR1 cDNA sequence in NM_000125 and human genome assembly hg19 [51]

responsible for regulating ESRI expression in addition to the A promoter.

While the A promoter and ENH1 appear to be the most utilized regulatory elements, the activation of other promoters may play a role in the transcriptional regulation of ESR1. deGraffenried et al. performed mutagenesis studies on specific regions of the B promoter, which caused a decrease in promoter activity relative to that of the wild-type construct in a these studies show that ENH1 is a major regulatory element 
luciferase assay [61]. This result suggests that maximum transcriptional activation of $E S R 1$ may require multiple regulatory elements. Therefore, studies focusing on ESR1 regulation should determine the involvement of multiple regulatory elements in order to fully characterize how ESR1 is regulated.

The compilation of large datasets in resources such as the UCSC Genome Browser and the ENCODE project have greatly expanded our view of the ESR1 gene structure. With the ENCODE project, information concerning the chromatin state, predicted regulatory elements, histone marks, transcriptional activity, and transcription factors of a genomic region for different cell lines are available for analysis. In Bailey et al., bioinformatics analyses of genome-wide association studies combined with ENCODE data for the regulatory environment of ESR1 provided insight on common singlenucleotide variants ( $\mathrm{SNVs}$ ) associated with breast cancer risk [60]. From these analyses, several SNVs were identified on regulatory elements associated with ESR1 expression. Using luciferase reporter assays, these SNVs were found to decrease the transactivation potential of these regulatory elements. Additionally, these SNVs were predicted to alter transcription factor chromatin binding on these elements, notably transcription factors known to regulate ESR1 expression such as GATA3 and SIN3A [26, 55, 62]. Studies like Bailey et al. serve as an example of how large sequencing datasets can better inform studies of the multiple transcriptional mechanisms that coordinately regulate ESR1 [60].

\section{Basal Regulation of ESR1}

ER is an essential regulator of physiological processes related to development, survival, and proliferation in breast cells in response to its physiological ligand, 17 $\beta$-estradiol (E2). Therefore, it is crucial to maintain ESR 1 expression. A number of transcription factors have been identified that aid in the maintenance of ESR1 expression in breast cancer cells (Table 1). Early studies identified potential regulators of ESR 1 by analyzing interactions with ESR 1 promoters via reporter gene and electrophoretic mobility shift assays. By these methods, AP-2 $\gamma$ (previously known as ERF-1) and a protein complex containing Sp1, Sp3, and USF-1 were discovered to associate with either the A or B promoters respectively and maintain ESR1 promoter activity [63, 64]. While the direct mechanism of how these transcription factors maintained ESR 1 expression was not further investigated, a number of transcription-associated proteins have since been reported to associate with Sp1 and AP- $2 \gamma$. These transcription factors are able to interact with metastasis-associated 1 (MTA1) and the co-activator p300 to positively regulate ESR1 expression [65-67]. FOXO3a, a member of the Forkhead transcription factor family, can bind to the A and B promoters in NF639 cells, and a dominant negative mutation affecting the transactivation domain caused loss of ER expression [68].

With the advent of chromatin immunoprecipitation (ChIP), several additional protein complexes and components of the transcriptional machinery were found to occupy specific genomic locations on ESR1. The tumor suppressor p53 forms a complex with transcriptional regulators CARM1, CBP, cJun, and $\mathrm{Sp} 1$ to bind to the A promoter and overexpression/ knockdown studies showed a direct correlation between p53 and ESR1 expression [69]. GATA3 knockout caused ESR1 and ER protein downregulation, and it is speculated that GATA3 may positively regulate ESR 1 via coordination with p300 and Pol II on ENH1 [55].

Early studies on the A promoter using luciferase assays showed weak basal transcriptional activity in the absence of E2, suggesting that additional chromatin components are involved in maintaining basal activity of the ESR1 gene. In coordination with transcriptional regulators of ESR1, an emerging area of study focuses on three-dimensional organization of chromatin. Studying transcriptional regulation of ESR1 often presents genomic information in a linear fashion. However, techniques that assess long-range chromatin interactions show how transcription factors and distal regulatory elements act in concert to regulate gene expression (techniques reviewed in [70]). Evidence of long-range chromatin interactions involving ESR 1 was described by Dunbier et al. in which ESR1 appeared to be co-regulated with neighboring genes CCDC170, ARMT1, and SYNE1 in ER-positive breast cancer patient samples [71]. Dunning et al. also utilized genome-wide association studies and found enhancer elements between CCDC170 and ESR1 that co-regulated ESR1, $R M N D 1$, and $C C D C 170$ [72]. As described earlier, Bailey et al. also observed co-repression of RMND1, ARMT, $C C D C 170$, and ESR1 following CRISPR knockout of a genomic region that is commonly mutated in breast cancer patients [60]. CCDC170 (Coiled-Coil Domain-Containing Protein 170) and ARMT1 (Acidic Residue Methyltransferase 1) have been implicated in breast cancers by causing Golgi reorganization and promoting cell proliferation, respectively [71, 73, 74]. The functions of RMND1 (Required for Meiotic Nuclear Division 1) and SYNE1 (Spectrin Repeat Containing Nuclear Envelope Protein) in breast cancer are unknown, but RMND1 has been reported to affect mitochondria translation in human subjects [75]. It should be noted that the coregulation of these genes may not always occur. YamamotoIbusuki et al. analyzed correlations between ESRI and its neighboring genes in breast cancer patient tissue and found higher CCDC170 expression correlated with ER negativity [76]. Nevertheless, this evidence suggests that the chromatin configuration around ESR1 is a point of regulation that may change with breast cancer risk and progression.

Using DNA motif analysis of this genomic region, Bailey et al. identified transcription factors that could be responsible 
Table 1 Transcriptional regulators of ESRI

\begin{tabular}{|c|c|c|c|}
\hline ESR1 regulator & Pos/Neg regulation? & Confirmed ESR1 genomic location or genomic coordinates (chr6) & Reference(s) \\
\hline ERUBF-1 & Potentially positive & Between B and C promoters $(-893$ to -859$)$ & {$[166]$} \\
\hline $\begin{array}{l}\mathrm{pRb} 2 / \mathrm{p} 130-\text { multimolecular } \\
\text { complex }\end{array}$ & Positive or negative & A promoter (chr6:152,128,814-152,128,940) & {$[167]$} \\
\hline MTA-1 & $\begin{array}{l}\text { Positive }(\mathrm{ER}+ \\
\text { cells)/negative } \\
(\mathrm{ER}-\text { cells })\end{array}$ & A promoter/exon $1(+146-+461)$ & {$[67]$} \\
\hline AIB1 & Positive & A promoter (+ 135), ENH1 (chr6:151,979,485-151,979,625) & {$[26]$} \\
\hline Cohesin & Positive & $\begin{array}{l}\text { Between E1 and F promoters (chr6:152,086,545-152,086,774) and between } \\
\text { exons } 1 \text { and } 2 \text { (chr6:152,445,477-152,445,760) }\end{array}$ & [78] \\
\hline GATA3 & Positive & $\begin{array}{l}\text { B promoter (chr6:152,128,313-152,128,608), E1 promoter } \\
\text { (chr6:152,022,992-152,023,729), ENH1 (chr6:151,979,485-151,979,625) }\end{array}$ & $\begin{array}{l}{[55,59,168,} \\
169]\end{array}$ \\
\hline $\mathrm{Sp} 1 / \mathrm{Sp} 3 / \mathrm{USF}-1$ & Positive & B promoter $(-245$ to -182$)$ & {$[61,170]$} \\
\hline p53 & Positive & $\begin{array}{l}\text { Between A and B promoters ( }-128 \text { to }-40) \text {, B promoter }(-350 \text { to }-289) \text {, and } \\
\text { between B and C promoters (chr6:152,127,935-152,128,177) }\end{array}$ & {$[69,171]$} \\
\hline Eleanors/u-Eleanors & Positive & Between E1 and T1 promoters (chr6: 152,080,078-152,424,447) & [172] \\
\hline AP- $-2 \gamma$ & Positive & A-D promoters $(-3500$ to +230$)$ & {$[59,173]$} \\
\hline BRCA1 & Positive/negative & $\begin{array}{l}\text { B promoter (chr6:152,128,428-152,128,644), near ENH1 } \\
\quad(151,979,263-151,979,349)\end{array}$ & {$[174,175]$} \\
\hline FOXM1 & Positive & $\begin{array}{l}\text { B promoter (chr6:152,128,376-152,128,588), C promoter } \\
\text { (chr6:152,125,599-152,125,948 and chr6:152,126,059-152,126,400) }\end{array}$ & {$[176]$} \\
\hline Pol II & Positive & $\begin{array}{l}\text { A promoter }(+135,+60), \text { B promoter }(\mathrm{chr} 6: 152,128,599-152,128,838), \mathrm{F} \\
\text { promoter }(\text { chr6:152,011,555-152,011,924), ENH1 } \\
(\text { chr6:151,979,485-151,979,625) }\end{array}$ & $\begin{array}{r}{[26,59} \\
177]\end{array}$ \\
\hline FOXA1 & Positive & $\begin{array}{l}\text { A promoter (chr6:152,128,599-152,128,838), B promoter } \\
\text { (chr6:152,128,428-152,128,644), ENH1 (chr6:151,979,485-151,979,625) }\end{array}$ & $\begin{array}{l}{[59,168,} \\
178]\end{array}$ \\
\hline ER & Negative & A promoter $(+135)$, B promoter (chr6:152,128,399-152,128,674) & {$[26,168]$} \\
\hline SNAI1 & Negative & A promoter $(\sim+1)$, Intron 1 & [129] \\
\hline TWIST & Negative & Between B and C promoters, Intron 7 (chr6: 152,458,034 (hg18)) & {$[131,132]$} \\
\hline SLUG/SNAI2 & Negative & $\sim \mathrm{A}$ promoter, between $\mathrm{B}$ and $\mathrm{C}$ promoters, and $\mathrm{C}$ promoter & [133] \\
\hline BLIMP1 & Negative & C promoter $(-2772$ to -2754$)$ & [111] \\
\hline SIN3A & Negative & A promoter $(+135)$ & {$[26]$} \\
\hline WT1 & Negative & B promoter (chr6:152,128,562-152,128,700) & [179] \\
\hline $\begin{array}{l}\text { Repressor complex (HDAC1, } \\
\text { DNMTs, MBDPs, MeCP2) }\end{array}$ & Negative & Exon 1 (chr6:152,129,124-152,129,274) & [108] \\
\hline FOXO3a & Negative & Between C and D promoters ( -3284 to -1864$)$ & {$[68]$} \\
\hline PR-B & Negative & Near C promoter $(-1757$ to -1752$)$ & {$[180]$} \\
\hline BARX2 & N/A & $\begin{array}{l}\text { ENH1 (chr6:151,977,586-151,978,005) and F promoter } \\
\quad(\text { chr6:152,011,374-152,011,630) }\end{array}$ & [181] \\
\hline ZBTB7A & Positive & Between B and C promoters $(-1381)$ & {$[182]$} \\
\hline MUC1-C & Negative & Exon 1 (chr6:152,011,575-152,011,670) & [183] \\
\hline MYOD & Negative & Exon $1(152,143,011-152,143,084)$ & {$[184]$} \\
\hline SALL2 & Positive & Near F promoter $(152,008,290-152,008,462)$ & {$[185]$} \\
\hline MLL, SET1A & Positive & $\begin{array}{l}\text { A promoter (chr6: } 152,128,814-152,128,940), \mathrm{F} \text { promoter (chr6: } \\
152,011,652-152,011,781)\end{array}$ & {$[186]$} \\
\hline CTCF & N/A & $\begin{array}{l}\text { B promoter (chr6:152,128,487-152,128,716), F promoter } \\
\quad(\text { chr6:152,011,363-152,011,792) }\end{array}$ & {$[177]$} \\
\hline MYC & N/A & B promoter (chr6:152,128,488-152,128,797) & {$[177]$} \\
\hline ZNF217 & N/A & E1 promoter (chr6:152,022,992-152,023,561) & [169] \\
\hline
\end{tabular}

for regulating this locus. Several of these predicted transcription factors are involved in modulating chromatin structures and in maintaining ESR1 expression [60]. For example, cohesin is a protein complex that commonly interacts with
CCCTC-binding factor (CTCF) binding sites and plays a critical role in stabilizing the topological organization of chromosomal loops formed by CTCF [77]. By knocking down the cohesin subunits SMC3 or Mediator, ESR1 expression 
decreased along with reduced Pol II occupancy on the A promoter [78]. Additionally, CTCF itself has been implicated in affecting ESR1 expression through several potential mechanisms. One mechanism involves interactions between the long noncoding RNA $u$-Eleanors and CTCF along with other positive coregulators of ESR1 such as GATA3, p300, and CEBPB in MCF-7 cells that underwent long-term E2 deprivation. Knockdown of $u$-Eleanors caused repression of ESR1, suggesting these noncoding RNAs positively regulate ESRI. Other possible mechanisms involve CTCF directly affecting ER-DNA binding and ESR1 enhancer activity that could lead to changes in ESRI expression [79, 80]. The importance of long-range chromatin interactions is further emphasized by Fullwood et al. [70]. They performed a comprehensive study showing that ER engages in long-range chromatin interactions across the genomic landscape to regulate genes [70]. In relation to ESR1, further study of the three-dimensional chromosomal architecture of ESRI will allow us to build a more comprehensive model of how all elements of transcriptional regulation coordinate to regulate $E S R 1$ gene expression.

\section{Negative Regulation of ESR1}

While ER is normally tightly regulated in order to modulate its transcriptional activity, disruption of this system has been associated with increased risk of breast cancer development as well as metastasis [81, 82]. Specifically, overexpression of ER has significant consequences related to enhanced proliferation of breast cancer cells, decreased sensitivity to endocrine therapies, and ligand-independent activation of the receptor. Targeted overexpression of ER in transgenic mice resulted in the development of ductal carcinoma in situ, and human breast cancer with higher ER expression directly correlated with the risk of developing atypical ductal hyperplasia [83, 84]. Overexpression of ER in MCF-7 breast cancer cells induced ligand-independent activation of ER and enhanced cell growth [85]. This constitutive ER activity could only be blocked by fulvestrant, a full ER antagonist, whereas tamoxifen was insufficient to do so. These downstream effects of ER overexpression were corroborated with the findings of Tolhurst et al. [86]. Copy number aberrations of ESR1, specifically amplification of the ESR 1 gene, have also been detected in some ER-positive breast cancers. While controversial, ESR1 amplification has been shown to correlate with responsiveness to endocrine therapies due to higher ER expression $[87,88]$. However, analysis of data from the TCGA Pan-Cancer Atlas and METABRIC using cBioPortal reveals that only a small percentage of breast tumors $(\sim 3 \%, n=2813)$ contain amplifications of ESR1 (Fig. 3) [89, 90]. Overall, these findings emphasize the importance of regulated control of ESR1 expression.
Downregulation of cell receptors is an essential and intricate process for modulating their activities following stimulation with their cognate ligand. ER is normally tightly regulated on multiple levels of regulation in a negative feedback loop upon E2 treatment. This is exemplified by the decrease in ESR1 mRNA levels in response to E2 [35, 91, 92]. We determined that E2-stimulated repression of ESR1 involves a rapid decrease in nascent ESR1 transcripts [26]. Furthermore, repression of ESR1 can be blocked with either tamoxifen or fulvestrant, showing E2 stimulates autoregulation of ESR1 [93]. To mediate ESR1 repression following E2 stimulation, ligand-bound ER binds to ESR1 regulatory elements, specifically the A promoter and ENH1 $[26,55]$. ER directly interacts with the repressor complex SIN3A at the proximal promoter [26]. SIN3A is a known scaffold protein for HDACs, and the recruitment of SIN3A was accompanied by a repressive chromatin environment, specifically an increase in H4K20me 3 on the A promoter, and a loss of Pol II occupancy [94, 95]. Knockdown of SIN3A prevented repression of ESR1 expression by E2, confirming that SIN3A plays a direct role in E2stimulated ER autoregulation. This work established a model of ESR1 transcriptional regulation in the ER autoregulatory system.

Dysregulation of the autoregulatory system, specifically mechanisms of transcriptional repression of ESR 1 , is a significant area of interest due to the potential role of ER downregulation in mediating endocrine therapy resistance. As stated previously, approximately $70 \%$ of primary breast tumors are classified as ER-positive, and the majority of these tumors maintain their ER-positive status but exhibit reduced ER expression in metastatic sites relative to the primary tumors $[2,5$, 21, 96-103]. For ER-negative breast cancers, hypermethylation of $\mathrm{CpG}$ islands on the ESRI A and B promoters was detected in tumor samples, and the magnitude of methylation on these promoters was directly correlated with poor response to endocrine therapies [104]. Hypermethylation also appears to increase with disease progression [105]. To study ESR1 methylation, the Davidson group utilized ER-negative breast cancer cell lines MDA-MB-231 and Hs578t and observed hypermethylation of the A promoter [106, 107]. Several DNA methyltransferases (DNMT1, DNMT3a, DNMT3b), methyl-binding proteins (MeCP2, MBD1, MBD2, MBD3), and the histone deacetylase 1 (HDAC1) were detected on $\mathrm{CpG}$ islands in the A promoter [107, 108]. To determine whether hypermethylation was responsible for loss of ER expression, MDA-MB-231 and Hs578t cells were treated with the DNMT inhibitor 5-aza-2'-deoxycytidine (5-aza), which restored ER expression in both cell lines and caused attenuated cell growth [108]. These cells were also treated with HDAC inhibitor trichostatin A (TSA) with similar results. Re-expression of ER also restored tamoxifen sensitivity to MDA-MB-231 cells, inhibiting their growth [109]. These results suggested that coordination between methylation and 
Fig. 3 Percent of invasive ductal carcinoma (IDC, $n=2440$ ) and invasive lobular carcinoma (ILC, $n=373$ ) cases with ESRI

genomic alterations. The data are derived from The Cancer Genome Atlas Research Network [Pan-Cancer Atlas; https://www. cancer.gov/tcga) and the METABRIC study $[164,165]$

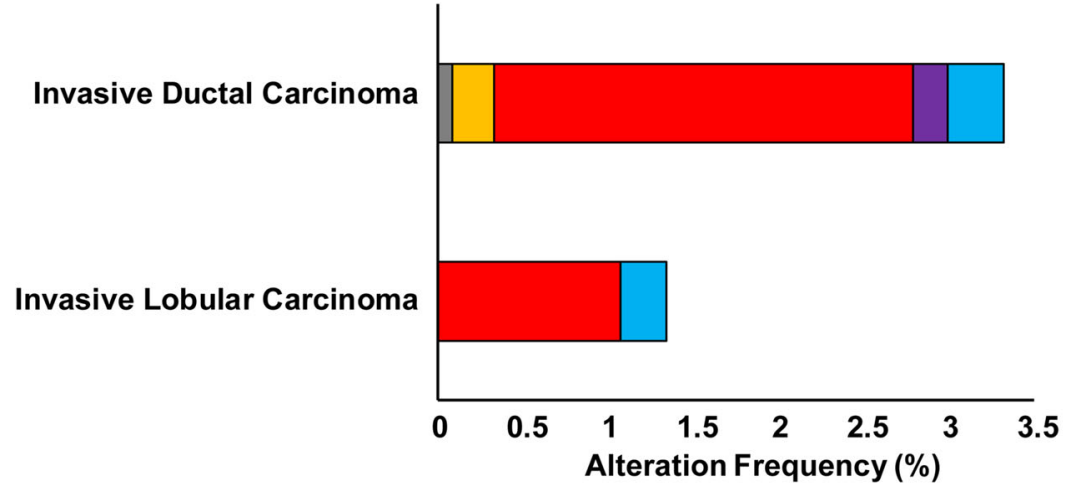

$\square$ Multiple Alterations $\quad$ Deep Deletion $\quad$ Amplification $\square$ Fusion deacetylation could facilitate both the generation and maintenance of a repressive chromatin environment on ESR1.

Prior to the recruitment of repressive complexes, signaling pathways and their associated transcription factors are also involved in repressing ESR1 expression. Three major signaling pathways associated with ESR1 transcriptional repression are the NF-KB, ERK/MAPK, and PI3K signaling pathways. NF- $\mathrm{KB}$ activation is inversely related to ER expression and constitutive activation of NF- $\mathrm{KB}$ is commonly found in ERnegative breast tumors [110]. Overexpression of the NF- $\mathrm{KB}$ subunit RelB in MCF-7, ZR-75-1, and NF639 (mouse breast cancer cell line) caused decreases in ESR1 mRNA and ER protein and an increase in the expression of the transcription factor BLIMP1. ZR-75-1 cells were transfected with a BLIMP1 expression vector, and BLIMP1 was found to bind to the ESR1 C promoter and repress ESR1 expression [111]. While not directly tested, BLIMP1 has been shown to recruit HDACs, histone methyltransferases (HMTs), and corepressor complexes [112-114]. ER-negative tumors also frequently overexpress growth factor receptors, notably epidermal growth factor (EGFR) and insulin-like growth factor receptor (IGF-1R) $[115,116]$. Unlike IGF-1R, EGFR has an inverse relationship with ER expression in breast cancer patient samples [117, 118]. Additionally, a recent study examining mammary organoid culture indicate that decreasing EGF in culture media promotes fully differentiated luminal A cell population [119]. The El-Ashry group has extensively studied the effects of hyperactivation of the ERK/MAPK signaling pathway on ER expression, which resulted in decreases in ESR1 mRNA and ER protein in MCF-7 cells expressing constitutively active Raf or MEK [120, 121]. To determine the mechanism behind ER downregulation, an epigenetic compound screen was used to identify potential regulators. Several HDAC inhibitors effectively relieved repression on ESR1 expression in ER-negative cell lines lacking a methylated ESR1 A promoter [121]. Class I HDACs (HDAC1, 2, and 3) were recruited with ERK2 along the ESR1 gene, encompassing the A-D promoters. Knockdown of both
MEK and class I HDACs increased ER expression by the greatest magnitude. Activation of the PI3K/mTOR signaling pathway in combination with the p70 S6 kinase (S6K1) has also been linked to decreases in ER expression. Inhibition of mTOR with rapamycin treatment caused overexpression of ER in MCF-7 cells, and restoration of tamoxifen sensitivity in hormone-resistant breast cancer cells in vitro and in vivo $[64,122]$.

While the common denominator in transcriptional regulation of ESR1 is modifications of the chromatin, clinical trials and in vitro studies indicate that epigenetic therapies have thus far not shown promise. Targeting HDACs and DNA methyltransferases have proven to be minimally effective in treating breast cancer patients with little, if any, improvement in survival rates (reviewed in [123]). One recent clinical trial treated patients with hormone-resistant disease (including triple negative breast cancer patients) with 5-aza and the HDAC inhibitor entinostat in combination with endocrine therapy [124]. Only 1 patient out of 27 ER-positive, endocrine therapyresistant patients exhibited any response to the combination of epigenetic and endocrine therapies [124]. Interestingly, no patients with triple-negative breast cancer exhibited a discernable increase in ER expression and only a few ER-positive tumors showed a minor increase in ER expression. Furthermore, prolonged treatment of MCF-7 cells with TSA actually causes a decrease in ESR1 mRNA and ER protein expression, specifically causing a decrease in ESR1 mRNA stability through the RNA binding protein $\operatorname{HuR}[122,125]$. These results suggest that specific targeting, as opposed to global modification of the epigenetic landscape, may be more effective at restoring ESR1 expression and endocrine therapy sensitivity.

Transcription factors are potential targets for relieving transcriptional repression of ESR1. Transcription factors that have been reported to repress ESRI are listed in Table 1 and presented in Fig. 4. The most notable set of transcription factors that transcriptionally repress ESR 1 expression are those associated with epithelial-to-mesenchymal transition (EMT), 


\section{ESR1}
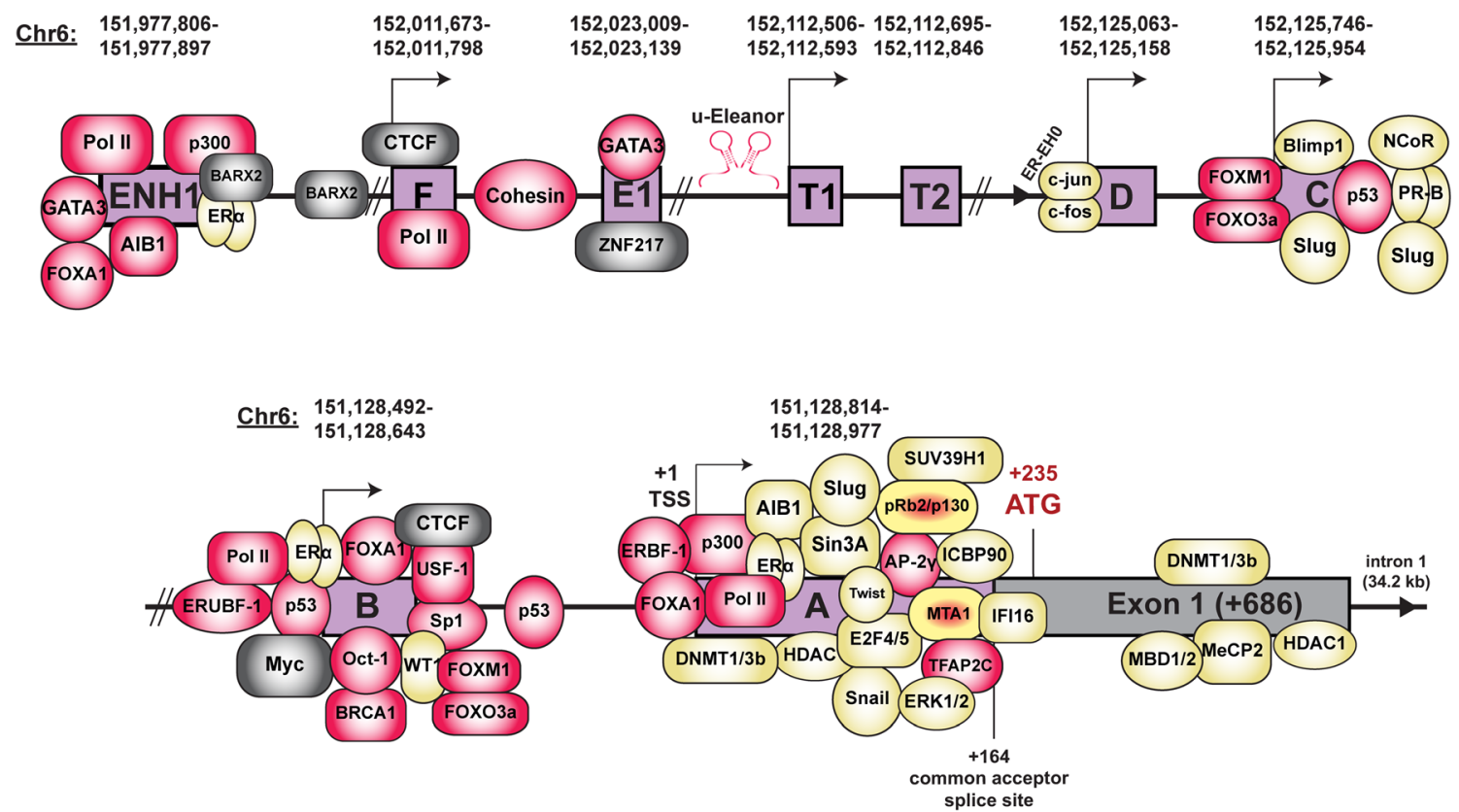

Fig. 4 Diagram of ESR 1 with transcription factors and co-factors. Shown are transcription factors involved in repressing (yellow) or maintaining basal ESRI expression (red). Transcription factors (TFs) that have dual repressive and activating roles are noted in yellow and red. TFs with

which include SNAI1, TWIST, and SLUG. All three transcription factors are commonly overexpressed in advanced stages of breast cancer, and their expression is often inversely correlated with that of ESRI [126-128]. Furthermore, breast tumors containing methylation of the ESRI promoter often also contain methylation of the E-cadherin gene ( $C D H 1)$, a gene that is transcriptionally repressed by these three EMT factors [105]. The overexpression of SNAI1 in MCF-7 cells induces an invasive phenotype and represses ESR1 mRNA expression. SNAI1 binds to the A promoter and reduces H3K9Ac (activating histone mark) but does not increase methylation on the H3K9 site (repressive histone mark), suggesting SNAI1 may only partially repress ESRI expression [129]. While no further details of the transcription mechanism were determined, SNAI1 can also recruit the SIN3A complex with $\mathrm{HDAC} 1 / 2$ on the $C D H 1$ promoter to repress its expression [130]. TWIST overexpression in MCF-7 cells conferred resistance to tamoxifen and repression of ESR1. To mediate transcriptional repression of ESR1, TWIST was recruited with DNMT3B and HDAC1 to the A promoter [131]. Fu et al. expanded on these findings by showing that TWIST interacted with one of the major HDAC complexes, the nucleosome remodeling and deacetylase repressor complex (NuRD) [132]. Using the DMT and HDAC inhibitors 5-aza and valproic acid, the repressive effects of TWIST on ESR1 repression were relieved and tamoxifen sensitivity was restored [131]. SLUG, also known as SNAI2, was found to bind unknown effects on ESRl expression are noted in gray. Genomic coordinates shown above each regulatory element are based on the UCSC Genome Browser (human genome assembly hg19) [51]. Diagram is not drawn to scale

to the ESR1 promoter as well and recruited the histone demethylase LSD1 for demethylating H3K4me2, an activating chromatin mark [133]. Knockdown of SLUG or LSD1 restored ESR1 expression, confirming their role in mediating transcriptional repression of ESR1. Examination of ENCODE data reveals that FOXA1 and GATA3 were commonly found across the ESR1 gene, specifically on the A, B, and E promoters [134]. The ENCODE project also revealed other transcription factors that have not been as extensively studied in the context of ESR1 regulation such as c-Myc and ZNF217.c$M y c$ is an ER target gene, and its expression is directly related to that of ESR $1 \mathrm{mRNA}$. c-Myc also directly interacts with ER to regulate gene expression [135]. c-Myc and ER both interact on the $\mathrm{B}$ promoter, suggesting potential regulation of ESRI by c-Myc and ER. ZNF217 is a Krüppel-like finger protein that can directly interact with ER and can facilitate recruitment of ER to an estrogen response element (ERE), where ER directly contacts the DNA at a palindromic sequence [136]. Furthermore, knockdown of ZNF217 appears to cause a decrease in ER protein expression, implicating ZNF217 as a positive regulator of ESR 1 expression.

Squelching has also been proposed as yet another mechanism of transcriptional regulation of ESR1. Squelching is the process of repressing gene expression by sequestering limited factors that regulate transcription such as co-activators and corepressors (reviewed in [137]). The mechanism was first described by Gill and Patshne using yeast that expressed 
derivatives of the GAL4 transcriptional activator. After overexpressing GAL4, the expression of genes lacking a GAL4 binding site decreased [138]. Based on this observation, it was suggested that genes containing GAL4 binding sites may be competing with other genes for transcription factors of a finite amount. Squelching was also reported to occur with steroid receptors [139]. By overexpressing ER lacking the DNA binding and dimerization domain, the transcriptional activity of both glucocorticoid receptors (GR) and progesterone receptors (PR) decreased, suggesting ER may be competing with both GR and PR for co-factors. Analyzing the effects on endogenous receptors, treatment of ER-positive breast cancer cell lines with progestin caused a decrease in ER transcriptional activity, suggesting PR may be utilizing co-factors that are important for ER transactivation. Co-factors related to ESR1 gene regulation that are implicated in a squelching mechanism include SRC-3 and p300 [140, 141]. ChIP-seq datasets of activating histone marks and these co-factors revealed a redistribution of both SRC-3 and p300 upon ligand activation. He et al. showed that overexpression of SRC-3 prevented the re-distribution of SRC-3 from non-E2-responsive genes, which is consistent with the squelching model [140]. For p300, Guertin et al. showed that p300 is bound to ESR1 in the absence of ligand, promoting basal ESR1 gene expression [141]. When activated, ER recruits p300 to activated genes, resulting in the redistribution of p300 and the loss of p300 at ESR1, leading to repression of ESR1 gene expression [141]. Given the prevalence of co-factors such as SRC-3 and p300 in transcriptional regulation by multiple transcription factors, the squelching mechanism may play a significant role in contextdependent modulation of ESR1 during disease progression.

\section{Transcriptional Regulation of ESR 1 by the Tumor Microenvironment}

A major contributor to the altered control of ER expression in breast tumor is the tumor microenvironment (TME). Evidence for regulation of ER expression by the TME is apparent based on clinical data showing either repression of ESR1 mRNA expression or downregulation of ER protein in metastatic samples relative to that in the patient-matched primary samples [20, 142]. Extrinsic TME-derived soluble factors (growth factors, cytokines, cholesterols, heavy metals, cell stress-related factors, exosomes, and other) have been reported to affect ER expression via paracrine interactions. Additionally, co-culture with a variety of cell types also induced repression of ESR I via mechanisms involving signaling pathways and cell stress. Tables 2 and 3 cite the factors and co-culture approaches that have been applied to the study of TME-associated regulation of ESR1. Despite the complexity and multiplicity of these paracrine interactions, regulation of ESR 1 expression is a convergence point. This highlights a generalized property that
TME-derived factors can promote breast cancer disease progression by diminishing ER expression and endocrine control.

To affect ESR1 expression, soluble factors, conditions promoting cell stress, and different cell types can transcriptionally, posttranscriptionally, or posttranslationally regulate ER expression. Of these mechanisms and given the complexity of ESR1 transcriptional regulation, the effects of the TME on ESR1 transcriptional regulation appears to be the least wellcharacterized. Growth factors are one of the most-studied factors in relation to breast cancer since these factors can alter sensitivity to hormone therapy and activate steroid receptors [143-151]. For example, Stoica et al. investigated the effects of three growth factors on ER expression: transforming growth factor $\beta$ (TGF- $\beta$ ), epidermal growth factor (EGF), and insulin-like growth factor (IGF-1) [152-154]. MCF-7 cells were treated with these growth factors and each growth factor caused a decrease in both ESR 1 mRNA and ER protein. Measuring ER protein half-life and ESR1 mRNA stability neither appeared to decrease following treatment with these growth factors. Using nuclear run-on assays, transcription of ESR 1 decreased significantly with TGF- $\beta$ and EGF treatment $[152,153]$. Since neither ER protein nor ESR1 mRNA stability changed with IGF-1 treatment, it is likely a transcriptional mechanism is involved in regulating ER expression with IGF1 as well [154]. While these three growth factors caused decreased expression of ESR 1 mRNA, several additional findings were observed for each growth factor. With TGF- $\beta$, the activity of the ESR 1 promoter (measured via chloramphenicol acetyltransferase reporter activity) decreased, suggesting transcriptional repression by TGF- $\beta$ may be mediated via the ESR1 promoter [153]. With EGF, serum was required in the cell culture media to induce transcriptional repression of ESR1, implicating that additional factors are required in order to coordinate with the effects of EGF and repress ESR1 [152]. With IGF-1, the PI3K signaling pathway and protein kinase $\mathrm{C}$ were required to repress ESR1 [154]. Despite the differences for how each growth factor regulates ESR1, transcriptional repression of ESRl appears to be a general mechanism by which the TME represses ER expression.

The cumulative effects of the TME has been primarily studied through co-culture with different cells in order to assess changes in tumor cell behavior. Given that multiple factors and cell types appear to regulate ER expression, our lab first addressed whether there is a degree of specificity in the ability of different cells to regulate ER expression. We directly co-cultured MCF-7 cells with a panel of cell lines and measured changes in ER protein expression [155]. We observed that only some of these cell lines were able to downregulate ER expression, which suggests that there is a degree of specificity in the regulation of ER expression that is not limited by cell type nor site of cell origin.

Decreases in ER expression by other cells have been shown to occur on multiple levels of regulation. Macrophages, 
Table 2 Extrinsic factors affecting ER expression

\begin{tabular}{|c|c|c|c|c|}
\hline Factors/signaling pathways & Cell model(s) & Effect on ER expression & Level of regulation (mechanism) & Reference \\
\hline $17 \beta$-Estradiol & MCF-7 & $\downarrow$ & $\begin{array}{l}\text { Transcriptional } \\
\text { Posttranscriptional } \\
\text { Posttranslational }\end{array}$ & {$[26,27,29,30,34,187]$} \\
\hline Epidermal growth factor & MCF-7 & $\downarrow$ & $\begin{array}{l}\text { Transcriptional } \\
\text { Posttranscriptional }\end{array}$ & {$[152,188]$} \\
\hline Insulin-like growth factor 1 & MCF-7 & $\downarrow$ & Transcriptional & {$[154]$} \\
\hline Transforming growth factor $\beta 1$ & MCF-7 & $\downarrow$ & Transcriptional & {$[153]$} \\
\hline Tumor necrosis factor $\alpha$ & MCF-7, ZR-75-1 & $\downarrow$ & Posttranslational & [189] \\
\hline 27-Hydroxycholesterol & MCF-7 & $\downarrow$ & Posttranslational & {$[190]$} \\
\hline Oncostatin M & MCF-7, T47D & $\downarrow$ & N/A & {$[191]$} \\
\hline Prolactin & MCF-7 & $\uparrow$ & N/A & {$[192]$} \\
\hline Reactive oxygen species & MCF-7 & $\downarrow$ & N/A & {$[193]$} \\
\hline Heavy metals & MCF-7 & $\downarrow$ & N/A & [194] \\
\hline Cadmium & MCF-7 & $\downarrow$ & Transcriptional & {$[195]$} \\
\hline ERK/MAPK & MCF-7 & $\downarrow$ & Transcriptional & {$[120,121,196]$} \\
\hline p38 MAPK & MCF-7 & $\downarrow$ & Posttranslational & {$[197]$} \\
\hline $\mathrm{PI} 3 \mathrm{~K} / \mathrm{mTOR} / \mathrm{Akt}$ & MCF-7, T47D & $\downarrow$ & Transcriptional & {$[122]$} \\
\hline Hypoxia & MCF-7, ZR-75-1 & $\downarrow$ & $\begin{array}{l}\text { Transcriptional } \\
\text { Posttranslational }\end{array}$ & {$[158,198]$} \\
\hline IL-1 $\beta$ & MCF-7 & $\downarrow$ & Transcriptional & [199] \\
\hline
\end{tabular}

adipocytes, and stromal cells mediate transcriptional repression of the ESR1 gene via different mechanisms. Stossi et al. co-cultured pro-inflammatory macrophages with MCF-7 cells and observed downregulation of ER protein and ESR $1 \mathrm{mRNA}$ [156]. Using an inhibitor screen of various signaling pathways, only inhibitors of the ERK/MAPK signaling pathway prevented the decrease in ER expression. To mediate repression of ESRI by macrophages, cJun was essential for the recruitment of ERK to multiple binding sites on the gene. While a direct mechanism of ESRI regulation by cJun or ERK was not described, Stossi et al. posit that macrophages regulate ER expression via direct ESR1 transcriptional repression. Yao-Borengasser et al. co-cultured human adipocytes with MCF-7 cells, which induced repression of ESR1 [157]. Through gene expression analysis of the co-cultured adipocytes, hypoxia inducible factor 1 subunit $\alpha(H I F 1 \alpha)$ gene expression was significantly elevated relative to monoculture. Knockdown of HIF $1 \alpha$ in the co-cultured MCF-7 cells relieved repression on ESR1. Given the role of HIF $1 \alpha$ in response to hypoxic conditions, Yao-Borengasser et al. proposed that adipocytes may generate hypoxic conditions to repress ESR1, but it should be noted that signs of hypoxia such as low oxygen and increased ROS production were not measured in this study [157]. However, their hypothesis was supported in a study by Ryu et al., which showed MCF-7 cells cultured in hypoxic conditions resulted in transcriptional repression of ESR 1 via HIF $1 \propto[158]$. Similar findings were also described in primary breast tumors samples [159].
Recently, the effects of the bone microenvironment on breast cancer cell behavior has been of significant interest. The bone is the most common site of breast cancer metastasis, and despite the majority of breast cancer metastases maintaining their ER-positive status, most bone metastases have reduced responsiveness to endocrine therapies [160]. To explain the disparity in responsiveness, Priedigkeit et al. showed 7 out of 11 bone metastases exhibited repressed ESR1 mRNA expression compared to that in patient-matched primary tumor samples [142]. This suggests that the decrease in responsiveness to endocrine therapies may be attributed (at least in part) to a concomitant decrease in ER expression.

Our lab first described that HS5 cells, a bone marrowderived cell line, regulated both ER protein and ESRI mRNA expression in both direct and indirect co-culture systems [155]. Our results regarding downregulation of ESR 1 expression by HS5 cells were corroborated by two additional publications, which reported that HS5 cells caused a decrease in both ER protein and ESR1 mRNA expression in ER-positive breast cancer cells [161, 162]. After assessing ESR1 mRNA and ER protein stability, we determined that transcriptional regulation of ESRl was primarily responsible for ER downregulation by bone marrow stromal cells (BMSCs) [163]. Specifically, conditioned media $(\mathrm{CM})$ from both cancer-associated BMSCs and HS5 cells caused a decrease in nascent ESR1 transcripts in both MCF-7 and T47D cells. HS5 CM treatment 
Table 3 Regulation of ER expression via co-culture with different cell types

\begin{tabular}{|c|c|c|c|c|c|}
\hline Cell type & $\begin{array}{l}\text { Breast cancer cell } \\
\text { line(s) }\end{array}$ & Co-culture method & $\triangle E S R 1$ mRNA & $\Delta$ ER protein & Reference \\
\hline Macrophages & MCF-7 & $\mathrm{CM}$ & $\downarrow$ & $\downarrow$ & {$[156]$} \\
\hline $\begin{array}{l}\text { Primary human mammary fibroblasts } \\
\text { (normal) }\end{array}$ & MCF-7, HMEC & $\begin{array}{l}\text { Indirect (3D), } \\
\quad \text { direct (3D), CM }\end{array}$ & $\downarrow$ & N/A & {$[200]$} \\
\hline Adipocytes & MCF-7 & Indirect (transwell) & $\downarrow$ & N/A & {$[157]$} \\
\hline Human mesenchymal stem cells & MDA-MB-231, T47D & $\begin{array}{l}\text { Indirect (transwell), } \\
\text { direct (in vivo } \\
\text { mouse study) }\end{array}$ & $\begin{array}{l}\text { Potential } \\
\quad \downarrow(\text { miR-221/222) }\end{array}$ & N/A & {$[201]$} \\
\hline $\begin{array}{l}\text { HS-5, HS-27a, primary human } \\
\text { fibroblasts (CD146-/+ } \\
\text { cancer-associated breast } \\
\text { cancer tissues) }\end{array}$ & MCF-7 & $\mathrm{CM}$ & $\downarrow$ & $\downarrow$ & {$[162]$} \\
\hline HS-5, HS-27a, KM101, hFOB & $\begin{array}{l}\text { MCF-7, T47D, } \\
\text { BT-474 }\end{array}$ & $\mathrm{CM}$ & $\downarrow$ & $\downarrow$ & {$[161]$} \\
\hline $\begin{array}{l}\text { HS-5, MDA-MB-231, MEF, } \\
\text { MDA-MB-468, HS578T, HEK293, } \\
\text { RMF/EG, MRC-5, THP-1, } \\
\text { SK-BR-3, CV-1, MCF10A, BT-20 }\end{array}$ & MCF-7, T47D & Direct & $\downarrow$ (HS-5) & $\begin{array}{l}\downarrow \text { (HS-5, RMF/EG, MRC-5, } \\
\text { MDA-MB-231, CV-1, } \\
\text { MCF10A, MDA-MB-468, } \\
\text { HS-578T, THP-1) }\end{array}$ & {$[155]$} \\
\hline HMF cell line & MCF-7 & Indirect (3D) & $\downarrow$ & $\downarrow$ & {$[202]$} \\
\hline $\begin{array}{l}\text { Primary human fibroblasts } \\
\text { (cancer-associated breast cancer } \\
\text { tissues) }\end{array}$ & MCF-7 & $\mathrm{CM}$ & $\begin{array}{l}\downarrow \text { (CAF derived } \\
\text { from basal } \\
\text { tumor) }\end{array}$ & $\begin{array}{l}\downarrow \text { (CAF derived from basal } \\
\quad \text { tumor) }\end{array}$ & [203] \\
\hline $\begin{array}{l}\text { Primary bone marrow stroma (normal } \\
\text { donors) }\end{array}$ & T47D, MDA-MB-231 & Direct & $\begin{array}{l}\text { Potential } \\
\quad \downarrow(\text { miR-221/222) }\end{array}$ & $\mathrm{N} / \mathrm{A}$ & [204] \\
\hline $\begin{array}{l}\text { Primary bone marrow stroma (normal } \\
\text { and cancer-associated), HS-5 }\end{array}$ & MCF-7, T47D & $\mathrm{CM}$ & $\downarrow$ & $\downarrow$ & {$[163]$} \\
\hline
\end{tabular}

decreased Pol II occupancy on the A promoter and ENH1 while H3K27Ac levels on ENH1 decreased in MCF-7 cells following HS5 CM treatment. The decrease in H3K27Ac levels suggest that ENH1 may play a major role in regulating ESRI by BMSCs. Interestingly, neighboring genes of ESR1 were also co-repressed in the presence of BMSC CM, similar to the pattern of co-regulation described by Bailey et al. and Dunning et al. As of this review, this was the first observation that suggested longrange chromatin interactions may be involved in ESRI regulation by the TME. Overall, the complexity of ESRI transcriptional repression is evident as ESRI appears to be regulated via different mechanisms in each study. However, further investigation is needed to determine how the chromatin environment is affected by the cumulative effects of the TME and, ultimately, general mechanisms behind ESR1 repression.

\section{Conclusions}

Over the past 30 years, the field has made significant strides in piecing together the components of ESR1 regulation, identifying a number of transcription factors, chromatin states, signaling pathways, and chromosomal arrangements that all play a role in regulating the gene. This regulation likely involves an intricate coordination of these elements, and new discoveries of additional transcription factors, regulatory elements, and long-range chromatin interactions as a result of large sequencing datasets will further our understanding of how ESRl is regulated. Considering the number of mechanisms affecting ESR1 expression, it is clear that modulating ER expression levels and ultimately hormone responsiveness is of significant biological importance. Dysregulation of ER expression has been implicated in the development of endocrine therapy resistance since ER expression levels directly correlates with endocrine therapy responsiveness. Continuing to investigate the mechanisms involved in dysregulation of ESR1 will ultimately provide insight on maintaining or even restoring the effectiveness of endocrine therapies in ER-positive breast cancer.

Acknowledgments We would like to thank Dr. Stephanie Ellison-Zelski for providing input on designing a model of the ESR1 gene and its known associated transcriptional regulators. We would also like to thank Dr. Mary S. Ozers for comments on this review.

Availability of Data and Material All datasets used in this review are cited in the figure captions.

Code Availability Not applicable 
Funding Information This work was supported by the National Institute of Health Grant T32 CA009135 (to D.K.L.) and McArdle Laboratory for Cancer Research.

\section{Compliance with Ethical Standards}

Conflict of Interest The authors declare they have no conflicts of interest.

Ethics Approval Not applicable

Consent to Participate Not applicable

Consent for Publication Not applicable

\section{References}

1. Harvey JM, Clark GM, Osborne CK, Allred DC (1999) Estrogen receptor status by immunohistochemistry is superior to the ligandbinding assay for predicting response to adjuvant endocrine therapy in breast cancer. J Clin Oncol 17:1474-1481

2. Stierer M, Rosen H, Weber R, Hanak H, Spona J, Tuchler H (1993) Immunohistochemical and biochemical measurement of estrogen and progesterone receptors in primary breast cancer. Correlation of histopathology and prognostic factors. Ann Surg 218:13-21

3. Allegra JC, Lippman ME, Thompson EB, Simon R, Barlock A, Green L, Huff KK, Do HM, Aitken SC, Warren R (1980) Estrogen receptor status: an important variable in predicting response to endocrine therapy in metastatic breast cancer. Eur J Cancer 16:323-331

4. Cook KL, Clarke PA, Parmar J, Hu R, Schwartz-Roberts JL, AbuAsab M, Warri A, Baumann WT, Clarke R (2014) Knockdown of estrogen receptor-alpha induces autophagy and inhibits antiestrogen-mediated unfolded protein response activation, promoting ROS-induced breast cancer cell death. FASEB Journal : official publication of the Federation of American Societies for Experimental Biology 28:3891-3905

5. Rosenberg PS, KA Barker, WF Anderson. 2015. Estrogen receptor status and the future burden of invasive and in situ breast cancers in the United States. J Natl Cancer Inst 107

6. Hammond ME, Hayes DF, Dowsett M, Allred DC, Hagerty KL, Badve S, Fitzgibbons PL, Francis G, Goldstein NS, Hayes M, Hicks DG, Lester S, Love R, Mangu PB, McShane L, Miller K, Osborne CK, Paik S, Perlmutter J, Rhodes A, Sasano H, Schwartz JN, Sweep FC, Taube S, Torlakovic EE, Valenstein P, Viale G, Visscher D, Wheeler T, Williams RB, Wittliff JL, Wolff AC (2010) Oncology American Society of Clinical, Pathologists College of American.. American Society of Clinical Oncology/ College of American Pathologists guideline recommendations for immunohistochemical testing of estrogen and progesterone receptors in breast cancer (unabridged version). Arch Pathol Lab Med 134:e48-e72

7. Allred DC, Brown P, Medina D (2004) The origins of estrogen receptor alpha-positive and estrogen receptor alpha-negative human breast cancer. Breast Cancer Research : BCR 6:240-245

8. Russo J, Ao X, Grill C, Russo IH (1999) Pattern of distribution of cells positive for estrogen receptor alpha and progesterone receptor in relation to proliferating cells in the mammary gland. Breast Cancer Res Treat 53:217-227
9. Rosen JM (2003) Hormone receptor patterning plays a critical role in normal lobuloalveolar development and breast cancer progression. Breast Dis 18:3-9

10. Walker KJ, McClelland RA, Candlish W, Blamey RW, Nicholson RI (1992) Heterogeneity of oestrogen receptor expression in normal and malignant breast tissue. Eur J Cancer 28:34-37

11. Welsh AW, Moeder CB, Kumar S, Gershkovich P, Alarid ET, Harigopal M, Haffty BG, Rimm DL (2011) Standardization of estrogen receptor measurement in breast cancer suggests falsenegative results are a function of threshold intensity rather than percentage of positive cells. J Clin Oncol 29:2978-2984

12. Chung W, Eum HH, Lee HO, Lee KM, Lee HB, Kim KT, Ryu HS, Kim S, Lee JE, Park YH, Kan Z, Han W, Park WY (2017) Single-cell RNA-Seq enables comprehensive tumour and immune cell profiling in primary breast cancer. Nat Commun 8:15081

13. Hong SP, Chan TE, Lombardo Y, Corleone G, Rotmensz N, Bravaccini S, Rocca A, Pruneri G, McEwen KR, Charles Coombes R, Barozzi I, Magnani L (2019) Single-cell transcriptomics reveals multi-step adaptations to endocrine therapy. Nat Commun 10

14. Nguyen QH, Pervolarakis N, Blake K, Ma D, Davis RT, James N, Phung AT, Willey E, Kumar R, Jabart E, Driver I, Rock J, Goga A, Khan SA, Lawson DA, Werb Z, Kessenbrock K (2018) Profiling human breast epithelial cells using single cell RNA sequencing identifies cell diversity. Nat Commun 9:2028

15. Petersen OW, Hoyer PE, van Deurs B (1987) Frequency and distribution of estrogen receptor-positive cells in normal, nonlactating human breast tissue. Cancer Res 47:5748-5751

16. Ricketts D, Turnbull L, Ryall G, Bakhshi R, Rawson NS, Gazet JC, Nolan C, Coombes RC (1991) Estrogen and progesterone receptors in the normal female breast. Cancer Res 51:1817-1822

17. EBCTCG (2005) Effects of chemotherapy and hormonal therapy for early breast cancer on recurrence and 15-year survival: an overview of the randomised trials. Lancet 365:1687-1717

18. Campbell FC, Blamey RW, Elston CW, Morris AH, Nicholson RI, Griffiths K, Haybittle JL (1981) Quantitative oestradiol receptor values in primary breast cancer and response of metastases to endocrine therapy. Lancet 2:1317-1319

19. Gyorffy B, Lanczky A, Eklund AC, Denkert C, Budczies J, Li Q, Szallasi Z (2010) An online survival analysis tool to rapidly assess the effect of 22,277 genes on breast cancer prognosis using microarray data of 1,809 patients. Breast Cancer Res Treat 123:725731

20. Cejalvo JM, Martinez de Duenas E, Galvan P, Garcia-Recio S, Burgues Gasion O, Pare L, Antolin S, Martinello R, Blancas I, Adamo B, Guerrero-Zotano A, Munoz M, Nuciforo P, Vidal M, Perez RM, Chacon Lopez-Muniz JI, Caballero R, Peg V, Carrasco E, Rojo F, Perou CM, Cortes J, Adamo V, Albanell J, Gomis RR, Lluch A, Prat A (2017) Intrinsic subtypes and gene expression profiles in primary and metastatic breast cancer. Cancer Res 77: 2213-2221

21. Dieci MV, Piacentini F, Dominici M, Omarini C, Goubar A, Ficarra G, Conte P, Guarneri V (2014) Quantitative expression of estrogen receptor on relapse biopsy for ER-positive breast cancer: prognostic impact. Anticancer Res 34:3657-3662

22. Webb P, Lopez GN, Greene GL, Baxter JD, Kushner PJ (1992) The limits of the cellular capacity to mediate an estrogen response. Mol Endocrinol 6:157-167

23. Saez RA, McGuire WL, Clark GM (1989) Prognostic factors in breast cancer. Semin Surg Oncol 5:102-110

24. Knight KA, Livingston RB, Gregory EJ, McGuire WL (1977) Estrogen receptor as an independent prognostic factor for early recurrence in breast cancer. Cancer Res 37:4969-4671

25. Cheang MC, Martin M, Nielsen TO, Prat A, Voduc D, RodriguezLescure A, Ruiz A, Chia S, Shepherd L, Ruiz-Borrego M, Calvo L, Alba E, Carrasco E, Caballero R, Tu D, Pritchard KI, Levine 
MN, Bramwell VH, Parker J, Bernard PS, Ellis MJ, Perou CM, Di Leo A, Carey LA (2015) Defining breast cancer intrinsic subtypes by quantitative receptor expression. Oncologist 20:474-482

26. Ellison-Zelski SJ, Solodin NM, Alarid ET (2009) Repression of ESR1 through actions of estrogen receptor alpha and Sin3A at the proximal promoter. Mol Cell Biol 29:4949-4958

27. Alarid ET, Bakopoulos N, Solodin N (1999) Proteasomemediated proteolysis of estrogen receptor: a novel component in autologous down-regulation. Mol Endocrinol 13:1522-1534

28. Preisler-Mashek MT, Solodin N, Stark BL, Tyriver MK, Alarid ET (2002) Ligand-specific regulation of proteasome-mediated proteolysis of estrogen receptor-alpha. Am J Physiol Endocrinol Metab 282:E891-E898

29. Nawaz Z, Lonard DM, Dennis AP, Smith CL, O'Malley BW (1999) Proteasome-dependent degradation of the human estrogen receptor. Proc Natl Acad Sci U S A 96:1858-1862

30. Castellano L, Giamas G, Jacob J, Coombes RC, Lucchesi W, Thiruchelvam P, Barton G, Jiao LR, Wait R, Waxman J, Hannon GJ, Stebbing J (2009) The estrogen receptor-alphainduced microRNA signature regulates itself and its transcriptional response. Proc Natl Acad Sci U S A 106:15732-15737

31. Pandey DP, Picard D (2009) miR-22 inhibits estrogen signaling by directly targeting the estrogen receptor alpha mRNA. Mol Cell Biol 29:3783-3790

32. Di Leva G, Gasparini P, Piovan C, Ngankeu A, Garofalo M, Taccioli C, Iorio MV, Li M, Volinia S, Alder H, Nakamura T, Nuovo G, Liu Y, Nephew KP, Croce CM (2010) MicroRNA cluster 221-222 and estrogen receptor alpha interactions in breast cancer. J Natl Cancer Inst 102:706-721

33. Adams BD, Furneaux H, White BA (2007) The micro-ribonucleic acid (miRNA) miR-206 targets the human estrogen receptor-alpha (ERalpha) and represses ERalpha messenger RNA and protein expression in breast cancer cell lines. Mol Endocrinol 21:11321147

34. Saceda M, Lindsey RK, Solomon H, Angeloni SV, Martin MB (1998) Estradiol regulates estrogen receptor mRNA stability. J Steroid Biochem Mol Biol 66:113-120

35. Saceda M, Lippman ME, Chambon P, Lindsey RL, Ponglikitmongkol M, Puente M, Martin MB (1988) Regulation of the estrogen receptor in MCF-7 cells by estradiol. Mol Endocrinol 2:1157-1162

36. Tian D, Solodin NM, Rajbhandari P, Bjorklund K, Alarid ET, Kreeger PK (2015) A kinetic model identifies phosphorylated estrogen receptor-alpha (ERalpha) as a critical regulator of ERalpha dynamics in breast cancer. FASEB Journal : official publication of the Federation of American Societies for Experimental Biology 29:2022-2031

37. Itoh M, Iwamoto T, Matsuoka J, Nogami T, Motoki T, Shien T, Taira N, Niikura N, Hayashi N, Ohtani S, Higaki K, Fujiwara T, Doihara H, Symmans WF, Pusztai L (2014) Estrogen receptor (ER) mRNA expression and molecular subtype distribution in ER-negative/progesterone receptor-positive breast cancers. Breast Cancer Res Treat 143:403-409

38. Iwamoto T, Booser D, Valero V, Murray JL, Koenig K, Esteva FJ, Ueno NT, Zhang J, Shi W, Qi Y, Matsuoka J, Yang EJ, Hortobagyi GN, Hatzis C, Symmans WF, Pusztai L (2012) Estrogen receptor (ER) mRNA and ER-related gene expression in breast cancers that are $1 \%$ to $10 \%$ ER-positive by immunohistochemistry. J Clin Oncol 30:729-734

39. Prat A, Adamo B, Cheang MC, Anders CK, Carey LA, Perou CM (2013) Molecular characterization of basal-like and non-basal-like triple-negative breast cancer. Oncologist 18:123-133

40. Walter P, Green S, Greene G, Krust A, Bornert JM, Jeltsch JM, Staub A, Jensen E, Scrace G, Waterfield M et al (1985) Cloning of the human estrogen receptor cDNA. Proc Natl Acad Sci U S A 82: 7889-7893
41. Green S, Walter P, Kumar V, Krust A, Bornert JM, Argos P, Chambon P (1986) Human oestrogen receptor cDNA: sequence, expression and homology to v-erb-A. Nature 320:134-139

42. Ponglikitmongkol M, Green S, Chambon P (1988) Genomic organization of the human oestrogen receptor gene. EMBO J 7: $3385-3388$

43. Keaveney M, Klug J, Dawson MT, Nestor PV, Neilan JG, Forde RC, Gannon F (1991) Evidence for a previously unidentified upstream exon in the human oestrogen receptor gene. $\mathrm{J}$ Mol Endocrinol 6:111-115

44. Grandien K (1996) Determination of transcription start sites in the human estrogen receptor gene and identification of a novel, tissuespecific, estrogen receptor-mRNA isoform. Mol Cell Endocrinol 116:207-212

45. Grandien KF, Berkenstam A, Nilsson S, Gustafsson JA (1993) Localization of DNase I hypersensitive sites in the human oestrogen receptor gene correlates with the transcriptional activity of two differentially used promoters. J Mol Endocrinol 10:269277

46. Piva R, Bianchi N, Aguiari GL, Gambari R, del Senno L (1993) Sequencing of an RNA transcript of the human estrogen receptor gene: evidence for a new transcriptional event. J Steroid Biochem Mol Biol 46:531-538

47. Tang Z, Treilleux I, Brown M (1997) A transcriptional enhancer required for the differential expression of the human estrogen receptor in breast cancers. Mol Cell Biol 17:1274-1280

48. Flouriot G, Griffin C, Kenealy M, Sonntag-Buck V, Gannon F (1998) Differentially expressed messenger RNA isoforms of the human estrogen receptor-alpha gene are generated by alternative splicing and promoter usage. Mol Endocrinol 12:1939-1954

49. Kos M, Reid G, Denger S, Gannon F (2001) Minireview: genomic organization of the human ERalpha gene promoter region. Mol Endocrinol 15:2057-2063

50. Brand H, Kos M, Denger S, Flouriot G, Gromoll J, Gannon F, Reid G (2002) A novel promoter is involved in the expression of estrogen receptor alpha in human testis and epididymis. Endocrinology 143:3397-3404

51. Kent WJ, Sugnet CW, Furey TS, Roskin KM, Pringle TH, Zahler AM, Haussler D (2002) The human genome browser at UCSC. Genome Res 12:996-1006

52. Reid G, Denger S, Kos M, Gannon F (2002) Human estrogen receptor-a: regulation by synthesis, modification and degradation. Cell Mol Life Sci 59:821-831

53. Inoue A, Hayashi S-i, Aoyagi K, Nishigaki M, Sasaki H, Kiyama R (2002) A reporter gene assay for evaluation of tissue-specific responses to estrogens based on the differential use of promoters A to $\mathrm{F}$ of the human estrogen receptor $\alpha$ gene. J Pharmacol Toxicol Methods 47:129-135

54. Higuchi T, Gohno T, Nagatomo T, Tokiniwa H, Niwa T, Horiguchi J, Oyama T, Takeyoshi I, Hayashi S (2014) Variation in use of estrogen receptor-alpha gene promoters in breast cancer compared by quantification of promoter-specific messenger RNA. Clin Breast Cancer 14:249-257

55. Eeckhoute J, Keeton EK, Lupien M, Krum SA, Carroll JS, Brown M (2007) Positive cross-regulatory loop ties GATA-3 to estrogen receptor alpha expression in breast cancer. Cancer Res 67:64776483

56. Asselin-Labat ML, Sutherland KD, Barker H, Thomas R, Shackleton M, Forrest NC, Hartley L, Robb L, Grosveld FG, van der Wees J, Lindeman GJ, Visvader JE (2007) Gata-3 is an essential regulator of mammary-gland morphogenesis and luminal-cell differentiation. Nat Cell Biol 9:201-209

57. Kouros-Mehr H, Slorach EM, Sternlicht MD, Werb Z (2006) GATA-3 maintains the differentiation of the luminal cell fate in the mammary gland. Cell 127:1041-1055 
58. Powers GL, Ellison-Zelski SJ, Casa AJ, Lee AV, Alarid ET (2010) Proteasome inhibition represses ERalpha gene expression in ER+ cells: a new link between proteasome activity and estrogen signaling in breast cancer. Oncogene 29:1509-1518

59. Powers GL, Rajbhandari P, Solodin NM, Bickford B, Alarid ET (2013) The proteasome inhibitor bortezomib induces an inhibitory chromatin environment at a distal enhancer of the estrogen receptor-alpha gene. PLoS One 8:e81110

60. Bailey SD, Desai K, Kron KJ, Mazrooei P, Sinnott-Armstrong NA, Treloar AE, Dowar M, Thu KL, Cescon DW, Silvester J, Yang SY, Wu X, Pezo RC, Haibe-Kains B, Mak TW, Bedard PL, Pugh TJ, Sallari RC, Lupien M (2016) Noncoding somatic and inherited single-nucleotide variants converge to promote ESR1 expression in breast cancer. Nat Genet 48:1260-1266

61. deGraffenried LA, Hilsenbeck SG, Fuqua SAW (2002) Sp1 is essential for estrogen receptor alpha gene transcription. J Steroid Biochem 82:7-18

62. Cowper-Sal lari R, Zhang X, Wright JB, Bailey SD, Cole MD, Eeckhoute J, Moore JH, Lupien M (2012) Breast cancer riskassociated SNPs modulate the affinity of chromatin for FOXA1 and alter gene expression. Nat Genet 44:1191-1198

63. deConinck EC, McPherson LA, Weigel RJ (1995) Transcriptional regulation of estrogen receptor in breast carcinomas. Mol Cell Biol 15:2191-2196

64. deGraffenried LA, Friedrichs WE, Russell DH, Donzis EJ, Middleton AK, Silva JM, Roth RA, Hidalgo M (2004) Inhibition of mTOR activity restores tamoxifen response in breast cancer cells with aberrant Akt activity. Clin Cancer Res 10:80598067

65. Li L, He S, Sun JM, Davie JR (2004) Gene regulation by Sp1 and Sp3. Biochem Cell Biol 82:460-471

66. Jiang Q, Zhang H, Zhang P (2011) ShRNA-mediated gene silencing of MTA1 influenced on protein expression of ER alpha, MMP-9, CyclinD1 and invasiveness, proliferation in breast cancer cell lines MDA-MB-231 and MCF-7 in vitro. J Exp Clin Cancer Res 30:60

67. Kang HJ, Lee MH, Kang HL, Kim SH, Ahn JR, Na H, Na TY, Kim YN, Seong JK, Lee MO (2014) Differential regulation of estrogen receptor alpha expression in breast cancer cells by metastasis-associated protein 1. Cancer Res 74:1484-1494

68. Guo S, Sonenshein GE (2004) Forkhead box transcription factor FOXO3a regulates estrogen receptor alpha expression and is repressed by the Her-2/neu/phosphatidylinositol 3-kinase/Akt signaling pathway. Mol Cell Biol 24:8681-8690

69. Shirley SH, Rundhaug JE, Tian J, Cullinan-Ammann N, Lambertz I, Conti CJ, Fuchs-Young R (2009) Transcriptional regulation of estrogen receptor-alpha by p53 in human breast cancer cells. Cancer Res 69:3405-3414

70. Fullwood MJ, Liu MH, Pan YF, Liu J, Xu H, Mohamed YB, Orlov YL, Velkov S, Ho A, Mei PH, Chew EG, Huang PY, Welboren WJ, Han Y, Ooi HS, Ariyaratne PN, Vega VB, Luo Y, Tan PY, Choy PY, Wansa KD, Zhao B, Lim KS, Leow SC, Yow JS, Joseph R, Li H, Desai KV, Thomsen JS, Lee YK, Karuturi RK, Herve T, Bourque G, Stunnenberg HG, Ruan X, Cacheux-Rataboul V, Sung WK, Liu ET, Wei CL, Cheung E, Ruan Y (2009) An oestrogen-receptor-alpha-bound human chromatin interactome. Nature 462:58-64

71. Dunbier AK, H Anderson, Z Ghazoui, E Lopez-Knowles, S Pancholi, R Ribas, S Drury, K Sidhu, A Leary, LA Martin, M Dowsett. 2011. ESR1 is co-expressed with closely adjacent uncharacterised genes spanning a breast cancer susceptibility locus at 6q25.1. PLoS Genet 7:e1001382

72. Dunning AM, K Michailidou, KB Kuchenbaecker, D Thompson, JD French, J Beesley, CS Healey, S Kar, KA Pooley, E LopezKnowles, E Dicks, D Barrowdale, NA Sinnott-Armstrong, RC Sallari, KM Hillman, S Kaufmann, H Sivakumaran, M Moradi
Marjaneh, JS Lee, M Hills, M Jarosz, S Drury, S Canisius, MK Bolla, J Dennis, Q Wang, JL Hopper, MC Southey, A Broeks, MK Schmidt, A Lophatananon, K Muir, MW Beckmann, PA Fasching, I Dos-Santos-Silva, J Peto, EJ Sawyer, I Tomlinson, B Burwinkel, F Marme, P Guenel, T Truong, SE Bojesen, H Flyger, A Gonzalez-Neira, JI Perez, H Anton-Culver, L Eunjung, V Arndt, H Brenner, A Meindl, RK Schmutzler, H Brauch, U Hamann, K Aittomaki, C Blomqvist, H Ito, K Matsuo, N Bogdanova, T Dork, A Lindblom, S Margolin, VM Kosma, A Mannermaa, CC Tseng, AH Wu, D Lambrechts, H Wildiers, J Chang-Claude, A Rudolph, P Peterlongo, P Radice, JE Olson, GG Giles, RL Milne, CA Haiman, BE Henderson, MS Goldberg, SH Teo, CH Yip, S Nord, AL Borresen-Dale, V Kristensen, J Long, W Zheng, K Pylkas, R Winqvist, IL Andrulis, JA Knight, P Devilee, C Seynaeve, J Figueroa, ME Sherman, K Czene, H Darabi, A Hollestelle, AM van den Ouweland, K Humphreys, YT Gao, XO Shu, A Cox, SS Cross, W Blot, Q Cai, M Ghoussaini, BJ Perkins, M Shah, JY Choi, D Kang, SC Lee, M Hartman, M Kabisch, D Torres, A Jakubowska, J Lubinski, P Brennan, S Sangrajrang, CB Ambrosone, AE Toland, CY Shen, PE Wu, N Orr, A Swerdlow, L McGuffog, S Healey, A Lee, M Kapuscinski, EM John, MB Terry, MB Daly, DE Goldgar, SS Buys, R Janavicius, L Tihomirova, N Tung, CM Dorfling, EJ van Rensburg, SL Neuhausen, B Ejlertsen, TV Hansen, A Osorio, J Benitez, R Rando, JN Weitzel, B Bonanni, B Peissel, S Manoukian, L Papi, L Ottini, I Konstantopoulou, P Apostolou, J Garber, MU Rashid, D Frost, Embrace L Izatt S Ellis A K Godwin, N Arnold, D Niederacher, K Rhiem, N BogdanovaMarkov, C Sagne, D Stoppa-Lyonnet, F Damiola, Gemo Study Collaborators, O M Sinilnikova, S Mazoyer, C Isaacs, KB Claes, K De Leeneer, M de la Hoya, T Caldes, H Nevanlinna, S Khan, AR Mensenkamp, Hebon M J Hooning, MA Rookus, A Kwong, E Olah, O Diez, J Brunet, MA Pujana, J Gronwald, T Huzarski, RB Barkardottir, R Laframboise, P Soucy, M Montagna, S Agata, MR Teixeira, Investigators kConFab, SK Park, N Lindor, FJ Couch, M Tischkowitz, L Foretova, J Vijai, K Offit, CF Singer, C Rappaport, CM Phelan, MH Greene, PL Mai, G Rennert, EN Imyanitov, PJ Hulick, KA Phillips, M Piedmonte, AM Mulligan, G Glendon, A Bojesen, M Thomassen, MA Caligo, SY Yoon, E Friedman, Y Laitman, A Borg, A von Wachenfeldt, H Ehrencrona, J Rantala, OI Olopade, PA Ganz, RL Nussbaum, SA Gayther, KL Nathanson, SM Domchek, BK Arun, G Mitchell, BY Karlan, J Lester, G Maskarinec, C Woolcott, C Scott, J Stone, C Apicella, R Tamimi, R Luben, KT Khaw, A Helland, V Haakensen, M Dowsett, PD Pharoah, J Simard, P Hall, M Garcia-Closas, C Vachon, G Chenevix-Trench, AC Antoniou, DF Easton, SL Edwards. 2016. Breast cancer risk variants at $6 \mathrm{q} 25$ display different phenotype associations and regulate ESR1, RMND1 and CCDC170. Nat Genet 48:374-386

73. Jiang P, Li Y, Poleshko A, Medvedeva V, Baulina N, Zhang Y, Zhou Y, Slater CM, Pellegrin T, Wasserman J, Lindy M, Efimov A, Daly M, Katz RA, Chen X (2017) The protein encoded by the CCDC170 breast cancer gene functions to organize the Golgimicrotubule network. EBioMedicine 22:28-43

74. Perry JJ, Ballard GD, Albert AE, Dobrolecki LE, Malkas LH, Hoelz DJ (2015) Human C6orf211 encodes Armt1, a protein carboxyl methyltransferase that targets PCNA and is linked to the DNA damage response. Cell Rep 10:1288-1296

75. Janer A, Antonicka H, Lalonde E, Nishimura T, Sasarman F, Brown GK, Brown RM, Majewski J, Shoubridge EA (2012) An RMND1 mutation causes encephalopathy associated with multiple oxidative phosphorylation complex deficiencies and a mitochondrial translation defect. Am J Hum Genet 91:737-743

76. Yamamoto-Ibusuki M, Yamamoto Y, Fujiwara S, Sueta A, Yamamoto S, Hayashi M, Tomiguchi M, Takeshita T, Iwase H (2015) C6ORF97-ESR1 breast cancer susceptibility locus: 
influence on progression and survival in breast cancer patients. Eur J Hum Genet 23:949-956

77. Sofueva S, Yaffe E, Chan WC, Georgopoulou D, Vietri Rudan M, Mira-Bontenbal H, Pollard SM, Schroth GP, Tanay A, Hadjur S (2013) Cohesin-mediated interactions organize chromosomal domain architecture. EMBO J 32:3119-3129

78. Prenzel T, F Kramer, U Bedi, S Nagarajan, T Beissbarth, SA Johnsen. 2012. Cohesin is required for expression of the estrogen receptor-alpha (ESR1) gene. Epigenet Chromatin 5

79. Achinger-Kawecka J, Valdes-Mora F, Luu PL, Giles KA, Caldon CE, Qu W, Nair S, Soto S, Locke WJ, Yeo-Teh NS, Gould CM, Du Q, Smith GC, Ramos IR, Fernandez KF, Hoon DS, Gee JMW, Stirzaker C, Clark SJ (2020) Epigenetic reprogramming at estrogen-receptor binding sites alters $3 \mathrm{D}$ chromatin landscape in endocrine-resistant breast cancer. Nat Commun 11:320

80. Korkmaz G, Manber Z, Lopes R, Prekovic S, Schuurman K, Kim Y, Teunissen H, Flach K, Wit E, Galli GG, Zwart W, Elkon R, Agami R (2019) A CRISPR-Cas9 screen identifies essential CTCF anchor sites for estrogen receptor-driven breast cancer cell proliferation. Nucleic Acids Res 47:9557-9572

81. Harrell JC, Dye WW, Harvell DM, Pinto M, Jedlicka P, Sartorius CA, Horwitz KB (2007) Estrogen insensitivity in a model of estrogen receptor positive breast cancer lymph node metastasis. Cancer Res 67:10582-10591

82. Khan SA, Sachdeva A, Naim S, Meguid MM, Marx W, Simon H, Halverson JD, Numann PJ (1999) The normal breast epithelium of women with breast cancer displays an aberrant response to estradiol. Cancer epidemiology, Biomarkers \& Prevention : a publication of the American Association for Cancer Research, cosponsored by the American Society of Preventive Oncology 8: 867-872

83. Frech MS, Halama ED, Tilli MT, Singh B, Gunther EJ, Chodosh LA, Flaws JA, Furth PA (2005) Deregulated estrogen receptor alpha expression in mammary epithelial cells of transgenic mice results in the development of ductal carcinoma in situ. Cancer Res 65:681-685

84. Barr FE, Degnim AC, Hartmann LC, Radisky DC, Boughey JC, Anderson SS, Vierkant RA, Frost MH, Visscher DW, Reynolds C (2011) Estrogen receptor expression in atypical hyperplasia: lack of association with breast cancer. Cancer Prev Res 4:435-444

85. Fowler AM, Solodin NM, Valley CC, Alarid ET (2006) Altered target gene regulation controlled by estrogen receptor-alpha concentration. Mol Endocrinol 20:291-301

86. Tolhurst RS, Thomas RS, Kyle FJ, Patel H, Periyasamy M, Photiou A, Thiruchelvam PT, Lai CF, Al-Sabbagh M, Fisher RA, Barry S, Crnogorac-Jurcevic T, Martin LA, Dowsett M, Charles Coombes R, Kamalati T, Ali S, Buluwela L (2011) Transient over-expression of estrogen receptor-alpha in breast cancer cells promotes cell survival and estrogen-independent growth. Breast Cancer Res Treat 128:357-368

87. Tomita S, Zhang Z, Nakano M, Ibusuki M, Kawazoe T, Yamamoto Y, Iwase H (2009) Estrogen receptor alpha gene ESR1 amplification may predict endocrine therapy responsiveness in breast cancer patients. Cancer Sci 100:1012-1017

88. Holst F, Stahl PR, Ruiz C, Hellwinkel O, Jehan Z, Wendland M, Lebeau A, Terracciano L, Al-Kuraya K, Janicke F, Sauter G, Simon R (2007) Estrogen receptor alpha (ESR1) gene amplification is frequent in breast cancer. Nat Genet 39:655-660

89. Cerami E, Gao J, Dogrusoz U, Gross BE, Sumer SO, Aksoy BA, Jacobsen A, Byrne CJ, Heuer ML, Larsson E, Antipin Y, Reva B, Goldberg AP, Sander C, Schultz N (2012) The cBio cancer genomics portal: an open platform for exploring multidimensional cancer genomics data. Cancer Discov 2:401-404

90. Gao MQ, Kim BG, Kang S, Choi YP, Park H, Kang KS, Cho NH (2010) Stromal fibroblasts from the interface zone of human breast carcinomas induce an epithelial-mesenchymal transition-like state in breast cancer cells in vitro. J Cell Sci 123:3507-3514

91. Read LD, Greene GL, Katzenellenbogen BS (1989) Regulation of estrogen-receptor messenger ribonucleic-acid and protein-levels in human-breast cancer cell-lines by sex steroid-hormones, their antagonists, and growth-factors. Mol Endocrinol 3:295-304

92. Berkenstam A, Glaumann H, Martin M, Gustafsson JA, Norstedt G (1989) Hormonal regulation of estrogen receptor messenger ribonucleic acid in T47Dco and MCF-7 breast cancer cells. Mol Endocrinol 3:22-28

93. Saceda M, Lippman ME, Lindsey RK, Puente M, Martin MB (1989) Role of an estrogen receptor-dependent mechanism in the regulation of estrogen receptor mRNA in MCF-7 cells. Mol Endocrinol 3:1782-1787

94. Hassig CA, Fleischer TC, Billin AN, Schreiber SL, Ayer DE (1997) Histone deacetylase activity is required for full transcriptional repression by $\mathrm{mSin} 3 \mathrm{~A}$. Cell 89:341-347

95. Zhang Y, Iratni R, Erdjument-Bromage H, Tempst P, Reinberg D (1997) Histone deacetylases and SAP18, a novel polypeptide, are components of a human Sin3 complex. Cell 89:357-364

96. Yao ZX, Lu LJ, Wang RJ, Jin LB, Liu SC, Li HY, Ren GS, Wu KN, Wang DL, Kong LQ (2014) Discordance and clinical significance of ER, PR, and HER2 status between primary breast cancer and synchronous axillary lymph node metastasis. Med Oncol 31: 798

97. Amir E, Clemons M, Purdie CA, Miller N, Quinlan P, Geddie W, Coleman RE, Freedman OC, Jordan LB, Thompson AM (2012) Tissue confirmation of disease recurrence in breast cancer patients: pooled analysis of multi-centre, multi-disciplinary prospective studies. Cancer Treat Rev 38:708-714

98. Amir E, Miller N, Geddie W, Freedman O, Kassam F, Simmons C, Oldfield M, Dranitsaris G, Tomlinson G, Laupacis A, Tannock IF, Clemons M (2012) Prospective study evaluating the impact of tissue confirmation of metastatic disease in patients with breast cancer. J Clin Oncol 30:587-592

99. Amir E, Ooi WS, Simmons C, Kahn H, Christakis M, Popovic S, Kalina M, Chesney A, Singh G, Clemons M (2008) Discordance between receptor status in primary and metastatic breast cancer: an exploratory study of bone and bone marrow biopsies. Clin Oncol (R Coll Radiol) 20:763-768

100. Broom RJ, Tang PA, Simmons C, Bordeleau L, Mulligan AM, O'Malley FP, Miller N, Andrulis IL, Brenner DM, Clemons MJ (2009) Changes in estrogen receptor, progesterone receptor and Her-2/neu status with time: discordance rates between primary and metastatic breast cancer. Anticancer Res 29:1557-1562

101. Curtit E, Nerich V, Mansi L, Chaigneau L, Cals L, Villanueva C, Bazan F, Montcuquet P, Meneveau N, Perrin S, Algros MP, Pivot X (2013) Discordances in estrogen receptor status, progesterone receptor status, and HER2 status between primary breast cancer and metastasis. Oncologist 18:667-674

102. Aitken SJ, Thomas JS, Langdon SP, Harrison DJ, Faratian D (2010) Quantitative analysis of changes in ER, PR and HER2 expression in primary breast cancer and paired nodal metastases. Ann Oncol 21:1254-1261

103. Li BDL, Byskosh A, Molteni A, Duda RB (1994) Estrogen and progesterone-receptor concordance between primary and recurrent breast-cancer. J Surg Oncol 57:71-77

104. Iwase H, Omoto Y, Iwata H, Toyama T, Hara Y, Ando Y, Ito Y, Fujii Y, Kobayashi S (1999) DNA methylation analysis at distal and proximal promoter regions of the oestrogen receptor gene in breast cancers. Brit J Cancer 80:1982-1986

105. Nass SJ, Herman JG, Gabrielson E, Iversen PW, Parl FF, Davidson NE, Graff JR (2000) Aberrant methylation of the estrogen receptor and E-cadherin 5' CpG islands increases with malignant progression in human breast cancer. Cancer Res 60:43464348 
106. Ottaviano YL, Issa JP, Parl FF, Smith HS, Baylin SB, Davidson NE (1994) Methylation of the estrogen receptor gene CpG island marks loss of estrogen receptor expression in human breast cancer cells. Cancer Res 54:2552-2555

107. Yan L, Nass SJ, Smith D, Nelson WG, Herman JG, Davidson NE (2003) Specific inhibition of DNMT1 by antisense oligonucleotides induces re-expression of estrogen receptor-alpha (ER) in ERnegative human breast cancer cell lines. Cancer Biology \& Therapy 2:552-556

108. Sharma D, Blum J, Yang X, Beaulieu N, Macleod AR, Davidson NE (2005) Release of methyl CpG binding proteins and histone deacetylase 1 from the estrogen receptor alpha (ER) promoter upon reactivation in ER-negative human breast cancer cells. Mol Endocrinol 19:1740-1751

109. Sharma D, Saxena NK, Davidson NE, Vertino PM (2006) Restoration of tamoxifen sensitivity in estrogen receptornegative breast cancer cells: tamoxifen-bound reactivated ER recruits distinctive corepressor complexes. Cancer Res 66:6370 6378

110. Nakshatri H, Bhat-Nakshatri P, Martin DA, Goulet RJ Jr, Sledge GW Jr (1997) Constitutive activation of NF-kappaB during progression of breast cancer to hormone-independent growth. Mol Cell Biol 17:3629-3639

111. Wang X, Belguise K, O'Neill CF, Sanchez-Morgan N, Romagnoli M, Eddy SF, Mineva ND, Yu Z, Min C, Trinkaus-Randall V, Chalbos D, Sonenshein GE (2009) RelB NF-kappaB represses estrogen receptor alpha expression via induction of the zinc finger protein Blimp1. Mol Cell Biol 29:3832-3844

112. Gyory I, Wu J, Fejer G, Seto E, Wright KL (2004) PRDI-BF1 recruits the histone $\mathrm{H} 3$ methyltransferase $\mathrm{G} 9 \mathrm{a}$ in transcriptional silencing. Nat Immunol 5:299-308

113. Ren B, Chee KJ, Kim TH, Maniatis T (1998) PRDI-BF1/Blimp-1 repression is mediated by corepressors of the Groucho family of proteins. Genes Dev 13:125-137

114. Yu J, Angelin-Duclos C, Greenwood J, Liao J, Calame K (2000) Transcriptional repression by blimp-1 (PRDI-BF1) involves recruitment of histone deacetylase. Mol Cell Biol 20:2592-2603

115. Sainsbury JR, Farndon JR, Sherbet GV, Harris AL (1985) Epidermal-growth-factor receptors and oestrogen receptors in human breast cancer. Lancet 1:364-366

116. Papa V, Gliozzo B, Clark GM, McGuire WL, Moore D, FujitaYamaguchi Y, Vigneri R, Goldfine ID, Pezzino V (1993) Insulinlike growth factor-I receptors are overexpressed and predict a low risk in human breast cancer. Cancer Res 53:3736-3740

117. Sharma AK, Horgan K, Douglas-Jones A, McClelland R, Gee J, Nicholson R (1994) Dual immunocytochemical analysis of oestrogen and epidermal growth factor receptors in human breast cancer. Br J Cancer 69:1032-1037

118. van Agthoven T, Timmermans M, Foekens JA, Dorssers LC, Henzen-Logmans SC (1994) Differential expression of estrogen, progesterone, and epidermal growth factor receptors in normal, benign, and malignant human breast tissues using dual staining immunohistochemistry. Am J Pathol 144:1238-1246

119. Rosenbluth JM, Schackmann RCJ, Gray GK, Selfors LM, Li CM, Boedicker M, Kuiken HJ, Richardson A, Brock J, Garber J, Dillon D, Sachs N, Clevers H, Brugge JS (2020) Organoid cultures from normal and cancer-prone human breast tissues preserve complex epithelial lineages. Nat Commun 11:1711

120. Oh AS, Lorant LA, Holloway JN, Miller DL, Kern FG, El-Ashry D (2001) Hyperactivation of MAPK induces loss of ER alpha expression in breast cancer cells. Mol Endocrinol 15:1344-1359

121. Plotkin A, Volmar CH, Wahlestedt C, Ayad N, El-Ashry D (2014) Transcriptional repression of ER through hMAPK dependent histone deacetylation by class I HDACs. Breast Cancer Res Treat 147:249-263
122. Citro S, Miccolo C, Meloni L, Chiocca S (2015) PI3K/mTOR mediate mitogen-dependent HDAC1 phosphorylation in breast cancer: a novel regulation of estrogen receptor expression. $\mathrm{J}$ Mol Cell Biol 7:132-142

123. Cai FF, Kohler C, Zhang B, Wang MH, Chen WJ, Zhong XY (2011) Epigenetic therapy for breast cancer. Int J Mol Sci 12: 4465-4487

124. Connolly RM, Li H, Jankowitz RC, Zhang Z, Rudek MA, Jeter SC, Slater SA, Powers P, Wolff AC, Fetting JH, Brufsky A, Piekarz R, Ahuja N, Laird PW, Shen H, Weisenberger DJ, Cope L, Herman JG, Somlo G, Garcia AA, Jones PA, Baylin SB, Davidson NE, Zahnow CA, Stearns V (2017) Combination epigenetic therapy in advanced breast cancer with 5-azacitidine and entinostat: a phase II National Cancer Institute/Stand Up to Cancer Study. Clin Cancer Res 23:2691-2701

125. Pryzbylkowski P, Obajimi O, Keen JC (2008) Trichostatin A and 5 Aza-2' deoxycytidine decrease estrogen receptor mRNA stability in ER positive MCF7 cells through modulation of HuR. Breast Cancer Res Treat 111:15-25

126. Moody SE, Perez D, Pan TC, Sarkisian CJ, Portocarrero CP, Sterner CJ, Notorfrancesco KL, Cardiff RD, Chodosh LA (2005) The transcriptional repressor Snail promotes mammary tumor recurrence. Cancer Cell 8:197-209

127. Mironchik Y, Winnard PT Jr, Vesuna F, Kato Y, Wildes F, Pathak AP, Kominsky S, Artemov D, Bhujwalla Z, Van Diest P, Burger H, Glackin C, Raman V (2005) Twist overexpression induces in vivo angiogenesis and correlates with chromosomal instability in breast cancer. Cancer Res 65:10801-10809

128. Martin TA, Goyal A, Watkins G, Jiang WG (2005) Expression of the transcription factors snail, slug, and twist and their clinical significance in human breast cancer. Ann Surg Oncol 12:488-496

129. Dhasarathy A, Kajita M, Wade PA (2007) The transcription factor snail mediates epithelial to mesenchymal transitions by repression of estrogen receptor-alpha. Mol Endocrinol 21:2907-2918

130. Peinado H, Ballestar E, Esteller M, Cano A (2004) Snail mediates E-cadherin repression by the recruitment of the Sin3A/histone deacetylase 1 (HDAC1)/HDAC2 complex. Mol Cell Biol 24: 306-319

131. Vesuna F, Lisok A, Kimble B, Domek J, Kato Y, van der Groep P, Artemov D, Kowalski J, Carraway H, van Diest P, Raman V (2011) Twist contributes to hormone resistance in breast cancer by downregulating estrogen receptor- $\alpha$. Oncogene 31:3223-3234

132. Fu J, Zhang L, He T, Xiao X, Liu X, Wang L, Yang L, Yang M, Zhang T, Chen R, Xu J (2012) TWIST represses estrogen receptor-alpha expression by recruiting the NuRD protein complex in breast cancer cells. Int J Biol Sci 8:522-532

133. Bai JW, Chen MN, Wei XL, Li YC, Lin HY, Chen M, Li JW, Du CW, Man K, Zhang GJ (2017) The zinc-finger transcriptional factor Slug transcriptionally downregulates ERalpha by recruiting lysine-specific demethylase 1 in human breast cancer. Oncogenesis 6:e330

134. Theodorou V, Stark R, Menon S, Carroll JS (2013) GATA3 acts upstream of FOXA1 in mediating ESR1 binding by shaping enhancer accessibility. Genome Res 23:12-22

135. Cheng AS, Jin VX, Fan M, Smith LT, Liyanarachchi S, Yan PS, Leu YW, Chan MW, Plass C, Nephew KP, Davuluri RV, Huang TH (2006) Combinatorial analysis of transcription factor partners reveals recruitment of c-MYC to estrogen receptor-alpha responsive promoters. Mol Cell 21:393-404

136. Nguyen NT, Vendrell JA, Poulard C, Gyorffy B, Goddard-Leon S, Bieche I, Corbo L, Le Romancer M, Bachelot T, Treilleux I, Cohen PA (2014) A functional interplay between ZNF217 and estrogen receptor alpha exists in luminal breast cancers. Mol Oncol 8:1441-1457

137. Cahill MA, Ernst WH, Janknecht R, Nordheim A (1994) Regulatory squelching. FEBS Lett 344:105-108 
138. Gill G, Ptashne M (1988) Negative effect of the transcriptional activator GAL4. Nature 334:721-724

139. Meyer ME, Gronemeyer H, Turcotte B, Bocquel MT, Tasset D, Chambon $\mathrm{P}$ (1989) Steroid-hormone receptors compete for factors that mediate their enhancer function. Cell 57:433-442

140. He HH, Meyer CA, Chen MW, Jordan VC, Brown M, Liu XS (2012) Differential DNase I hypersensitivity reveals factordependent chromatin dynamics. Genome Res 22:1015-1025

141. Guertin MJ, Zhang X, Coonrod SA, Hager GL (2014) Transient estrogen receptor binding and p300 redistribution support a squelching mechanism for estradiol-repressed genes. Mol Endocrinol 28:1522-1533

142. Priedigkeit N, Watters RJ, Lucas PC, Basudan A, Bhargava R, Horne W, Kolls JK, Fang Z, Rosenzweig MQ, Brufsky AM, Weiss KR, Oesterreich S, Lee AV (2017) Exome-capture RNA sequencing of decade-old breast cancers and matched decalcified bone metastases. JCI Insight 2:e95703

143. Ignar-Trowbridge DM, Teng CT, Ross KA, Parker MG, Korach KS, McLachlan JA (1993) Peptide growth factors elicit estrogen receptor-dependent transcriptional activation of an estrogenresponsive element. Mol Endocrinol 7:992-998

144. Bunone G, Briand PA, Miksicek RJ, Picard D (1996) Activation of the unliganded estrogen receptor by EGF involves the MAP kinase pathway and direct phosphorylation. EMBO J 15:2174 2183

145. Cavailles V, Garcia M, Rochefort H (1989) Regulation of cathepsin-D and pS2 gene expression by growth factors in MCF7 human breast cancer cells. Mol Endocrinol 3:552-558

146. Nunez AM, Berry M, Imler JL, Chambon P (1989) The 5' flanking region of the $\mathrm{pS} 2$ gene contains a complex enhancer region responsive to oestrogens, epidermal growth factor, a tumour promoter (TPA), the c-Ha-ras oncoprotein and the c-jun protein. EMBO J 8:823-829

147. Kato S, Endoh H, Masuhiro Y, Kitamoto T, Uchiyama S, Sasaki H, Masushige S, Gotoh Y, Nishida E, Kawashima H, Metzger D, Chambon P (1995) Activation of the estrogen-receptor through phosphorylation by mitogen-activated protein-kinase. Science 270:1491-1494

148. Divekar SD, Storchan GB, Sperle K, Veselik DJ, Johnson E, Dakshanamurthy S, Lajiminmuhip YN, Nakles RE, Huang L, Martin MB (2011) The role of calcium in the activation of estrogen receptor-alpha. Cancer Res 71:1658-1668

149. Becker MA, Ibrahim YH, Cui X, Lee AV, Yee D (2011) The IGF pathway regulates ERalpha through a S6K1-dependent mechanism in breast cancer cells. Mol Endocrinol 25:516-528

150. Campbell RA, Bhat-Nakshatri P, Patel NM, Constantinidou D, Ali S, Nakshatri H (2001) Phosphatidylinositol 3-kinase/AKT-mediated activation of estrogen receptor alpha: a new model for antiestrogen resistance. J Biol Chem 276:9817-9824

151. Lee AV, Weng CN, Jackson JG, Yee D (1997) Activation of estrogen receptor-mediated gene transcription by IGF-I in human breast cancer cells. J Endocrinol 152:39-47

152. Stoica A, Saceda M, Doraiswamy VL, Coleman C, Martin MB (2000) Regulation of estrogen receptor-alpha gene expression by epidermal growth factor. J Endocrinol 165:371-378

153. Stoica A, Saceda M, Fakhro A, Harrison BS, Fenster BD, Martin MB (1997) The role of transforming growth factor-beta in the regulation of estrogen receptor expression in the MCF-7 breast cancer cell line. Endocrinology 138:1498-1505

154. Stoica A, Saceda M, Fakhro A, Joyner M, Martin MB (2000) Role of insulin-like growth factor-1 in regulating estrogen receptoralpha gene expression. J Cell Biochem 76:605-614

155. Lang JD, Berry SM, Powers GL, Beebe DJ, Alarid ET (2013) Hormonally responsive breast cancer cells in a microfluidic coculture model as a sensor of microenvironmental activity.
Integrative Biology : Quantitative Biosciences from Nano to Macro 5:807-816

156. Stossi F, Madak-Erdogan Z, Katzenellenbogen BS (2012) Macrophage-elicited loss of estrogen receptor-alpha in breast cancer cells via involvement of MAPK and c-Jun at the ESR1 genomic locus. Oncogene 31:1825-1834

157. Yao-Borengasser A, Monzavi-Karbassi B, Hedges RA, Rogers LJ, Kadlubar SA, Kieber-Emmons T (2015) Adipocyte hypoxia promotes epithelial-mesenchymal transition-related gene expression and estrogen receptor-negative phenotype in breast cancer cells. Oncol Rep 33:2689-2694

158. Ryu K, Park C, Lee Y (2011) Hypoxia-inducible factor 1 alpha represses the transcription of the estrogen receptor alpha gene in human breast cancer cells. Biochem Biophys Res Commun 407: $831-836$

159. Lloyd MC, Alfarouk KO, Verduzco D, Bui MM, Gillies RJ, Ibrahim ME, Brown JS, Gatenby RA (2014) Vascular measurements correlate with estrogen receptor status. BMC Cancer 14: 279

160. Coleman RE, Rubens RD (1987) The clinical course of bone metastases from breast cancer. Br J Cancer 55:61-66

161. Huang J, Woods P, Normolle D, Goff JP, Benos PV, Stehle CJ, Steinman RA (2016) Downregulation of estrogen receptor and modulation of growth of breast cancer cell lines mediated by paracrine stromal cell signals. Breast Cancer Res Treat 161:229-243

162. Brechbuhl HM, Finlay-Schultz J, Yamamoto TM, Gillen AE, Cittelly DM, Tan AC, Sams SB, Pillai MM, Elias AD, Robinson WA, Sartorius CA, Kabos P (2017) Fibroblast subtypes regulate responsiveness of luminal breast cancer to estrogen. Clin Cancer Res 23:1710-1721

163. Lung DK, Warrick JW, Hematti P, Callander NS, Mark CJ, Miyamoto S, Alarid ET (2019) Bone marrow stromal cells transcriptionally repress ESR1 but cannot overcome constitutive ESR1 mutant activity. Endocrinology 160:2427-2440

164. Hoadley KA, Yau C, Hinoue T, Wolf DM, Lazar AJ, Drill E, Shen R, Taylor AM, Cherniack AD, Thorsson V, Akbani R, Bowlby R, Wong CK, Wiznerowicz M, Sanchez-Vega F, Robertson AG, Schneider BG, Lawrence MS, Noushmehr H, Malta TM, Network Cancer Genome Atlas, Stuart JM, Benz CC, Laird PW (2018) Cell-of-origin patterns dominate the molecular classification of 10,000 tumors from 33 types of cancer. Cell 173(291-304): e296

165. Pereira B, Chin SF, Rueda OM, Vollan HK, Provenzano E, Bardwell HA, Pugh M, Jones L, Russell R, Sammut SJ, Tsui DW, Liu B, Dawson SJ, Abraham J, Northen H, Peden JF, Mukherjee A, Turashvili G, Green AR, McKinney S, Oloumi A, Shah S, Rosenfeld N, Murphy L, Bentley DR, Ellis IO, Purushotham A, Pinder SE, Borresen-Dale AL, Earl HM, Pharoah PD, Ross MT, Aparicio S, Caldas C (2016) The somatic mutation profiles of 2,433 breast cancers refines their genomic and transcriptomic landscapes. Nat Commun 7:11479

166. Cohn CS, Sullivan JA, Kiefer T, Hill SM (1999) Identification of an enhancer element in the estrogen receptor upstream region: implications for regulation of ER transcription in breast cancer. Mol Cell Endocrinol 158:25-36

167. Macaluso M, Cinti C, Russo G, Russo A, Giordano A (2003) pRb2/p130-E2F4/5-HDAC1-SUV39H1-p300 and pRb2/p130E2F4/5-HDAC1-SUV39H1-DNMT1 multimolecular complexes mediate the transcription of estrogen receptor-alpha in breast cancer. Oncogene 22:3511-3517

168. Gertz J, Reddy TE, Varley KE, Garabedian MJ, Myers RM (2012) Genistein and bisphenol A exposure cause estrogen receptor 1 to bind thousands of sites in a cell type-specific manner. Genome Res 22:2153-2162

169. Snyder M, M Gerstein, S Weissman, PJ Farnham, K Struhl: ENCODE Transcription Factor Binding Sites by ChIP-seq from 
Stanford/Yale/USC/Harvard (GSE31477). http://www. encodeproject.org/, 2011,

170. deGraffenried LA, Hopp TA, Valente AJ, Clark RA, Fuqua SA (2004) Regulation of the estrogen receptor alpha minimal promoter by Sp1, USF-1 and ERalpha. Breast Cancer Res Treat 85:111120

171. Angeloni SV, Martin MB, Garcia-Morales P, Castro-Galache MD, Ferragut JA, Saceda M (2004) Regulation of estrogen receptor-alpha expression by the tumor suppressor gene p53 in MCF-7 cells. J Endocrinol 180:497-504

172. Tomita S, Abdalla MO, Fujiwara S, Matsumori H, Maehara K, Ohkawa Y, Iwase H, Saitoh N, Nakao M (2015) A cluster of noncoding RNAs activates the ESR1 locus during breast cancer adaptation. Nat Commun 6:6966

173. McPherson LA, Weigel RJ (1999) AP2alpha and AP2gamma: a comparison of binding site specificity and trans-activation of the estrogen receptor promoter and single site promoter constructs. Nucleic Acids Res 27:4040-4049

174. Hosey AM, Gorski JJ, Murray MM, Quinn JE, Chung WY, Stewart GE, James CR, Farragher SM, Mulligan JM, Scott AN, Dervan PA, Johnston PG, Couch FJ, Daly PA, Kay E, McCann A, Mullan PB, Harkin DP (2007) Molecular basis for estrogen receptor alpha deficiency in BRCA1-linked breast cancer. J Natl Cancer Inst 99:1683-1694

175. Chiang HC, Zhang X, Li J, Zhao X, Chen J, Wang HT, Jatoi I, Brenner A, Hu Y, Li R (2019) BRCA1-associated R-loop affects transcription and differentiation in breast luminal epithelial cells. Nucleic Acids Res 47:5086-5099

176. Madureira PA, Varshochi R, Constantinidou D, Francis RE, Coombes RC, Yao KM, Lam EW (2006) The Forkhead box M1 protein regulates the transcription of the estrogen receptor alpha in breast cancer cells. J Biol Chem 281:25167-25176

177. Furey TS, Z Zhang, L Song, G Crawford, P Giresi, J Lieb, Z Liu, R McDaniell, B Lee, VR Iyer, P Flicek, D Keefe, E Birney, S Graf: Open Chromatin TFBS by ChIP-seq from ENCODE/Open Chrom(UT Austin) (GSE33213). http://www.encodeproject.org, 2011,

178. Bernardo GM, Lozada KL, Miedler JD, Harburg G, Hewitt SC, Mosley JD, Godwin AK, Korach KS, Visvader JE, Kaestner KH, Abdul-Karim FW, Montano MM, Keri RA (2010) FOXA1 is an essential determinant of ERalpha expression and mammary ductal morphogenesis. Development 137:2045-2054

179. Han Y, Yang L, Suarez-Saiz F, San-Marina S, Cui J, Minden MD (2008) Wilms' tumor 1 suppressor gene mediates antiestrogen resistance via down-regulation of estrogen receptor-alpha expression in breast cancer cells. Mol Cancer Res 6:1347-1355

180. De Amicis F, Zupo S, Panno ML, Malivindi R, Giordano F, Barone I, Mauro L, Fuqua SA, Ando S (2009) Progesterone receptor B recruits a repressor complex to a half-PRE site of the estrogen receptor alpha gene promoter. Mol Endocrinol 23:454 465

181. Stevens TA, Meech R (2006) BARX2 and estrogen receptor-alpha (ESR1) coordinately regulate the production of alternatively spliced ESR1 isoforms and control breast cancer cell growth and invasion. Oncogene 25:5426-5435

182. Molloy ME, Lewinska M, Williamson AK, Nguyen TT, KuserAbali G, Gong L, Yan J, Little JB, Pandolfi PP, Yuan ZM (2018) ZBTB7A governs estrogen receptor alpha expression in breast cancer. J Mol Cell Biol 10:273-284

183. Hata T, Rajabi H, Takahashi H, Yasumizu Y, Li W, Jin C, Long MD, Hu Q, Liu S, Fushimi A, Yamashita N, Kui L, Hong D, Yamamoto M, Miyo M, Hiraki M, Maeda T, Suzuki Y, Samur MK, Kufe D (2019) MUC1-C activates the NuRD complex to drive dedifferentiation of triple-negative breast cancer cells. Cancer Res 79:5711-5722
184. Zhang Q, Liu XY, Li S, Zhao Z, Li J, Cui MK, Wang EH (2017) Repression of ESR1 transcription by MYOD potentiates letrozoleresistance in ERalpha-positive breast cancer cells. Biochem Biophys Res Commun 492:425-433

185. Ye L, Lin C, Wang X, Li Q, Li Y, Wang M, Zhao Z, Wu X, Shi D, Xiao Y, Ren L, Jian Y, Yang M, Ou R, Deng G, Ouyang Y, Chen X, Li J, Song L (2019) Epigenetic silencing of SALL2 confers tamoxifen resistance in breast cancer. EMBO Mol Med 11:e10638

186. Kim SS, Lee MH, Lee MO (2020) Histone methyltransferases regulate the transcriptional expression of ERalpha and the proliferation of tamoxifen-resistant breast cancer cells. Breast Cancer Res Treat

187. El Khissiin A, Leclercq G (1999) Implication of proteasome in estrogen receptor degradation. FEBS Lett 448:160-166

188. Adams BD, Cowee DM, White BA (2009) The role of miR-206 in the epidermal growth factor (EGF) induced repression of estrogen receptor-alpha (ERalpha) signaling and a luminal phenotype in MCF-7 breast cancer cells. Mol Endocrinol 23:1215-1230

189. Bhat-Nakshatri P, Campbell RA, Patel NM, Newton TR, King AJ, Marshall MS, Ali S, Nakshatri H (2004) Tumour necrosis factor and PI3-kinase control oestrogen receptor alpha protein level and its transrepression function. Br J Cancer 90:853-859

190. DuSell CD, Umetani M, Shaul PW, Mangelsdorf DJ, McDonnell DP (2008) 27-Hydroxycholesterol is an endogenous selective estrogen receptor modulator. Mol Endocrinol 22:65-77

191. West NR, Murphy LC, Watson PH (2012) Oncostatin M suppresses oestrogen receptor-alpha expression and is associated with poor outcome in human breast cancer. Endocr Relat Cancer 19: 181-195

192. Gutzman JH, Miller KK, Schuler LA (2004) Endogenous human prolactin and not exogenous human prolactin induces estrogen receptor alpha and prolactin receptor expression and increases estrogen responsiveness in breast cancer cells. J Steroid Biochem Mol Biol 88:69-77

193. Weitsman GE, Weebadda W, Ung K, Murphy LC (2009) Reactive oxygen species induce phosphorylation of serine 118 and 167 on estrogen receptor alpha. Breast Cancer Res Treat 118:269-279

194. Martin MB, Reiter R, Pham T, Avellanet YR, Camara J, Lahm M, Pentecost E, Pratap K, Gilmore BA, Divekar S, Dagata RS, Bull JL, Stoica A (2003) Estrogen-like activity of metals in MCF-7 breast cancer cells. Endocrinology 144:2425-2436

195. Garcia-Morales P, Saceda M, Kenney N, Kim N, Salomon DS, Gottardis MM, Solomon HB, Sholler PF, Jordan VC, Martin MB (1994) Effect of cadmium on estrogen receptor levels and estrogen-induced responses in human breast cancer cells. J Biol Chem 269:16896-16901

196. Creighton CJ, Hilger AM, Murthy S, Rae JM, Chinnaiyan AM, El-Ashry D (2006) Activation of mitogen-activated protein kinase in estrogen receptor alpha-positive breast cancer cells in vitro induces an in vivo molecular phenotype of estrogen receptor alphanegative human breast tumors. Cancer Res 66:3903-3911

197. Bhatt S, Xiao Z, Meng Z, Katzenellenbogen BS (2012) Phosphorylation by p38 mitogen-activated protein kinase promotes estrogen receptor alpha turnover and functional activity via the SCF(Skp2) proteasomal complex. Mol Cell Biol 32: 1928-1943

198. Stoner M, Saville B, Wormke M, Dean D, Burghardt R, Safe S (2002) Hypoxia induces proteasome-dependent degradation of estrogen receptor alpha in ZR-75 breast cancer cells. Mol Endocrinol 16:2231-2242

199. Jimenez-Garduno AM, Mendoza-Rodriguez MG, Urrutia-Cabrera D, Dominguez-Robles MC, Perez-Yepez EA, Ayala-Sumuano JT, Meza I (2017) IL-1beta induced methylation of the estrogen receptor ERalpha gene correlates with EMT and chemoresistance in breast cancer cells. Biochem Biophys Res Commun 490:780-785 
200. Holton SE, Bergamaschi A, Katzenellenbogen BS, Bhargava R (2014) Integration of molecular profiling and chemical imaging to elucidate fibroblast-microenvironment impact on cancer cell phenotype and endocrine resistance in breast cancer. PLoS One 9: e96878

201. Bliss SA, Sinha G, Sandiford OA, Williams LM, Engelberth DJ, Guiro K, Isenalumhe LL, Greco SJ, Ayer S, Bryan M, Kumar R, Ponzio NM, Rameshwar P (2016) Mesenchymal stem cell-derived exosomes stimulate cycling quiescence and early breast cancer dormancy in bone marrow. Cancer Res 76:5832-5844

202. Morgan MM, Livingston MK, Warrick JW, Stanek EM, Alarid ET, Beebe DJ, Johnson BP (2018) Mammary fibroblasts reduce apoptosis and speed estrogen-induced hyperplasia in an organotypic MCF7-derived duct model. Sci Rep 8:7139
203. Shah SH, Miller P, Garcia-Contreras M, Ao Z, Machlin L, Issa E, El-Ashry D (2015) Hierarchical paracrine interaction of breast cancer associated fibroblasts with cancer cells via hMAPKmicroRNAs to drive ER-negative breast cancer phenotype. Cancer Biology \& Therapy 16:1671-1681

204. Lim PK, Bliss SA, Patel SA, Taborga M, Dave MA, Gregory LA, Greco SJ, Bryan M, Patel PS, Rameshwar P (2011) Gap junctionmediated import of microRNA from bone marrow stromal cells can elicit cell cycle quiescence in breast cancer cells. Cancer Res $71: 1550-1560$

Publisher's Note Springer Nature remains neutral with regard to jurisdictional claims in published maps and institutional affiliations. 